\title{
Study of the degradation behavior of heat-treated jack pine (Pinus banksiana) under artificial sunlight irradiation
}

Xianai Huang ${ }^{\mathrm{a}}$, Duygu Kocaefe ${ }^{* a}$, Yasar Kocaefe ${ }^{\mathrm{a}}$, Yaman Boluk ${ }^{\mathrm{b}}$, Andre Pichette ${ }^{\mathrm{a}}$

${ }^{a}$ Université du Québec à Chicoutimi, Canada

555, boul. de l'Université, Chicoutimi Québec Canada G7H 2B1

dkocaefe@uqac.ca

1-418-545 5011-5215

$1-418-545-5012$

${ }^{\mathrm{b}}$ Alberta Research Council, Forest Products Business Unit

250 Karl Clark Road, Edmonton, Alberta Canada T6N 1E4 ${ }^{1}$

\begin{abstract}
Heat-treated wood, a relatively new product treated at high temperatures of 180 to $260^{\circ} \mathrm{C}$, possesses new versatile and attractive properties, which make it popular for outdoor applications. It is of considerable importance to investigate the influence of sunlight on the weathering degradation processes. In order to understand the degradation processes, kiln-dried (untreated) and heat-treated $\left(210^{\circ} \mathrm{C}\right)$ jack pine woods (Pinus banksiana) were exposed to artificial sunlight irradiation for different periods. Before and after exposure, their color and wettability by water were determined. Structural changes and chemical modifications at exposed surfaces were also investigated using SEM, FTIR spectroscopy, and XPS. SEM studies show that degradation of middle lamellar, checking of cell wall and destruction of bordered pits were observed on heat-treated wood surface due to sunlight irradiation. FTIR spectroscopy and XPS studies on the behavior of function groups of lignin and the oxygen to carbon ratios have revealed that the photo-degradation of lignin and presence of extractives play important roles in discoloration and wetting behavior of heat-treated wood surfaces during irradiation. The structural changes also influence the wettabilty of samples.
\end{abstract}

Keywords: heat-treated wood, sunlight irradiation degradation, discoloration, contact angle, SEM, FTIR, XPS

\footnotetext{
${ }^{1}$ Present address: Yaman Boluk: University of Alberta, Canada 3-142 Markin/CNRL Natural Resources Engineering Facility Edmonton, Alberta, Canada T6G 2W2
} 


\section{Introduction}

Wood is commonly used as engineering and structural material because of its versatile and attractive properties such as mechanical strength, low density, low thermal expansion, and aesthetic appeal [1]. Growth of the wood products industry has been accompanied by a significant expansion in the use of wood in outdoor applications. However, wood, similar to other biological materials, is susceptible to environmental degradation. Wood undergoes degradation induced by weathering factors such as solar radiation (ultraviolet (UV), visible, and infrared light), moisture (dew, rain, snow, and humidity), temperature, and oxygen [2]. Among these factors, UV radiation which is a part of solar radiation is known to be mainly responsible for initiating variety of chemical changes and discoloration of wood surfaces [1, 2]. Wood, a composite of cellulose, hemicelluloses, lignin, and extractives, is capable of absorbing all wavelengths of electromagnetic radiation which initiates photodegradation [3]. The degradation of wood due to weathering has been the subject of many research papers, review articles and books in connection with chemical changes, physical changes and structural changes. Several investigations on the color changes of commercial woods during weathering have been carried out [4-6] and they indicate that the chemical changes take place in wood during weathering. It is well accepted that the untreated wood changes color because of the photo-degradation of lignin and extractives [2]. Lin and Kringstad [7] reported that $\alpha$-carbonyl, biphenyl and ring-conjugated double bond structures in lignin can absorb UV-light and react with oxygen to form chromophoric groups as carbonyl and carboxyl groups [3]. This photochemical reactions occurring in lignin are responsible for the wood color changes. Microscopic changes accompany the color changes and chemical changes of wood during weathering. A series of papers reveal the breakdown of wood structure caused by weathering [8-16]. The observed changes can be summarized as the enlargement of apertures of bordered pits, consequently, formation of microchecks, destruction of the middle lamella together with the various layers of the cell wall, and the presentation of longitudinal checks on cell walls.

Heat-treated wood is a relatively new product treated at high temperatures in the range of 180 and $260^{\circ} \mathrm{C}$. Heat treatment modifies wood both chemically and physically. Chemical changes occurring due to heat treatment at high temperatures are decrease of amorphous polysaccharide content (hemicelluloses), condensation and demethoxylation of lignin, and removal of certain extractives $[1,17,18]$. Consequently, heat-treated wood possesses 
new physical properties such as reduced hygroscopy, improved dimensional stability, better resistance to degradation by insects and micro-organisms, and most importantly, attractive darker color. These new versatile and attractive properties make heat-treated wood become popular for outdoor applications.

However, studies have also shown that weathering results in poor aesthetics for heat-treated wood because of the discoloration and surface checking when exposed to UV radiation [17, 19-22]. Several reports are available on the study of color and dimensional stability after natural and accelerated weathering of heat-treated wood [1, 21, 23-30]. Most of the previous studies on weathering of heat-treated wood were limited to discoloration. A complete understanding of the mechanisms involved in weathering process would allow the development of new treatments and finishes that would greatly enhance durability of heat-treated wood and provide greater protection against degradation due to weathering. However, many aspects of weathering of heat-treated wood are not completely understood. Investigations on the wettability changes, chemical changes and microscopic changes of heat-treated wood after exposure to artificial sunlight irradiation are very limited and there is not any publication available in the literature on degradation taking place due to the sunlight irradiation of jack pine wood samples used in this study.

The objectives of this study are to investigate the mechanisms of degradation of heat-treated regional jack pine, to understand chemical and physical changes taking place, and to identify stages of these changes when the heattreated wood is exposed to artificial sunlight irradiation for various periods. In order to attain this research goal, several techniques and tools for the study of heat-treated wood surfaces were used such as datacolor meter for color measurement, contact angle measurement for wettability analysis, Fourier transforms infrared spectroscopy (FTIR) and X-ray photoelectron spectroscopy (XPS) for chemical analysis, and scanning electron spectroscopy (SEM) for microscopic structural analysis. These provide a great deal of insight into the degradation process for both heattreated and untreated jack pine exposed to artificial sunlight irradiation. These techniques allow in-depth study of heat treatment and modification of wood surface by solar radiation.

\section{Materials and methods}

\subsection{Testing materials}

Jack pine (Pinus banksiana), commonly used for outdoor applications in North America, was studied. The wood samples were obtained from ISA Industries, Normandin, Quebec. The heat-treatment was carried out using Finish 
ThermoWood technology at the maximum temperature of $210^{\circ} \mathrm{C}$. Specimens for experimental study were arbitrarily selected for a complete statistical randomization. The untreated wood boards were kiln dried with the final moisture content of about $12 \%$. Both heat-treated and untreated wood samples were exposed to artificial sunlight irradiation for comparison purposes. They were stored in a room at $20^{\circ} \mathrm{C}$ and $40 \%$ relative humidity until they were exposed to the artificial sunlight irradiation and the characterization tests described below.

Two series of specimens of $200 \times 70 \mathrm{~mm}$ cross-section and $20 \mathrm{~mm}$ width were cut from sapwood of heat-treated wood boards. The cross-section of one series was on longitudinal tangential surface (LT) and the other one was on longitudinal radial surface (LR). The study of untreated reference wood was carried on longitudinal tangential surface (LT). Both heat-treated and untreated specimens were then planed in order to smooth the surfaces.

The above specimens were exposed to artificial sunlight irradiation during artificial weathering tests. The analysis of the samples (color measurement, contact angle test, FTIR analysis, XPS analysis and SEM evaluation) were carried out on both longitudinal tangential (LT) surface [31] and longitudinal radial (LR) surface for heat-treated wood and on LT surface for untreated wood. The color measurements were carried out directly on the specimens' surfaces. For other tests, they were further cut to desired dimensions. Samples of $20 \times 20 \times 70 \mathrm{~mm}$ in the radial, tangential, and longitudinal directions, respectively, were prepared for surface wettability tests (contact angle measurement). For FTIR analysis and SEM evaluation samples had dimensions of $10 \times 20 \times 20 \mathrm{~mm}$ in the radial, tangential, and longitudinal directions, respectively, whereas small wood chips (approximately $10 \times 10$ on exposed surface and 1mm width) were cut to be used for XPS analysis.

\subsection{Artificial sunlight irradiation(UV-vis irradiation) tests}

Artificial sunlight exposure test was conducted at South Florida Test Service, Accelerated Weathering Laboratory, using an Atlas Ci65/Ci65A Xenon Weather-Ometer. This device used a controlled irradiance water-cooled xenon arc with a CIRA inner filter and a Soda outer filter as the source of radiation to simulate sunlight. The tests were performed according to standard of ASTM G 147-02. The program cycle was continuous xenon light without dark cycle to simulate the natural sunlight radiation and to accelerate the weathering process. There was no water spray but relative humidity was kept constant at $50 \pm 5 \%$. The black panel temperature was $63 \pm 3^{\circ} \mathrm{C}$ and irradiance level was $0.55 \mathrm{~W} / \mathrm{m}^{2}$ at $340 \mathrm{~nm}$ under these conditions. The longitudinal tangential (LT) and longitudinal radial (LR) surfaces of heat-treated samples and tangential surface (LT) of untreated control samples were exposed to the light 
source. The irradiation was interrupted after 72, 168, 336, 672, 1008, and 1500 hours of exposure and samples from each set of samples (untreated or heat treated under different experimental conditions) were taken out at the end of each exposure time for evaluation of surface properties. They were stored in the room at $20^{\circ} \mathrm{C}$ and $40 \%$ relative humidity until they were subjected to the characterization tests described below.

\subsection{Color determination}

The surface color of specimens exposed to artificial sun light for different periods was measured using colorimeter (datacolor, CHECK TM) with a measuring head which has diameter of $10 \mathrm{~mm}$. The color system $\mathrm{L} * \mathrm{a} * \mathrm{~b} *$ according to the CIELab (Commission Internationale d'Eclairage) standard [32] was used. The system is characterized by three parameters, $\mathrm{L}^{*}, \mathrm{a}^{*}$ and $\mathrm{b}^{*}$. A three-dimensional coordinate is assigned in the CIEL*a*b* color space. The $\mathrm{L}^{*}$ represents the lightness intensity ranging from 0 to 100 , where 0 represents black and 100 represents white. The $\mathrm{a}^{*}$ value describes the chromatic coordinates on the green/red axis, ranging from -127 (pure green) to +127 (pure red). The $b^{*}$ value represents the position on the blue/yellow axis, ranging from -127 (pure blue) to +127 (pure yellow). The difference in the lightness $\left(\Delta \mathrm{L}^{*}\right)$, the chromaticity coordinates ( $\Delta \mathrm{a}^{*}$ and $\left.\Delta \mathrm{b}^{*}\right)$ for the specimens before and after exposure of artificial sunlight irradiation were calculated according to the following equations based on a D65 light source by simulating the daylight:

$$
\begin{aligned}
& \Delta \mathrm{L}=\mathrm{L}_{\mathrm{t}}^{*}-\mathrm{L}_{0}^{*} \\
& \Delta \mathrm{a}=\mathrm{a}_{\mathrm{t}}^{*}-\mathrm{a}_{0}^{*} \\
& \Delta \mathrm{b}=\mathrm{b}_{\mathrm{t}}^{*}-\mathrm{b}_{0}^{*}
\end{aligned}
$$

where the subscript " 0 " represents the values before artificial sunlight irradiation, and " $\mathrm{t}$ " denotes those after exposure of $t h$.

The total color difference $(\Delta \mathrm{E})$ was calculated as a function of the artificial sunlight exposure time according to the equation given below.

$$
\Delta \mathrm{E}=\left(\Delta \mathrm{L}^{* 2}+\mathrm{a}^{* 2}+\mathrm{b}^{* 2}\right)^{\frac{1}{2}}
$$

\subsection{Surface wettability tests}

Wetting parameters obtained with water were significantly correlated with coating adhesion [33, 34]. Surface wettability experiments were performed using distilled water. Measurement of contact angle was performed at room 
condition of $20{ }^{\circ} \mathrm{C}$ and $40 \% \mathrm{RH}$. The contact angles between water and latewood specimen surfaces were determined using a sessile-drop system, First Ten Angstroms FTA200, equipped with CCD camera and image analysis software. The system uses video image processing which makes the faster determination of dynamic contact angles possible compared to the conventional contact angle goniometry. The initial period after trigger was $0.033 \mathrm{~s}$ and the post-trigger period multiplier was set up to 1.1. A drop of test liquid with volume of $15 \mu \mathrm{l}$ was dosed automatically by an auto-syringe and picked up by the specimen $(20 \times 20 \times 70 \mathrm{~mm})$ placed on a movable sample table. Measurements of contact angle were carried out by sessile drop profile method with a view across to the grain. The wetting process parallel to the grain was investigated. Six to twelve tests were performed for each set of experimental conditions. The contact angles between each droplet and specimen surface were measured both on the left side and the right side of the droplet and the mean contact angles were automatically calculated. Images of the drop in contact with the substrate were continuously captured at full video speed. The dynamic contact angles data were used to assess wood surface wettability.

\subsection{FTIR spectroscopy analysis}

The effect of sunlight irradiation on chemical compositions of both cellulose and lignin, and cellulose crystallinity on wood surface were studied using Fourier transform infrared spectroscopy. The air-dried specimens $(10 \times 20 \times 20$ mm) were studied using Jasco FT/IR 4200 equipped with a diamond micro-ATR crystal. IR spectra were recorded in the wave number range of $550-4000 \mathrm{~cm}^{-1}$ at $4 \mathrm{~cm}^{-1}$ resolutions for 20 scans prior to the Fourier transformation. The UV radiation penetrated only $75 \mu \mathrm{m}$ whereas visible light penetrated $200 \mu \mathrm{m}$ of wood surface [35, 36]. The incident angle of the micro-ATR crystal was $47^{\circ}$ corresponding to the sampling depth of infrared radiation of $0.2-5 \mu \mathrm{m}$, depending on the wave number. This ensured that the recorded IR spectra of wood surfaces were considered to be sufficiently surface sensitive. Thus, changes in IR spectral features were solely caused by changes in surface chemistry and there was no change of underlying bulk chemistry of the wood specimen. The aperture diameter was 7.1mm. All spectra were analyzed using Jasco spectra manager software. The IR spectra for each set experimental condition were transformed into absorbance spectra. The FTIR spectra were corrected by the FTIR software package which includes an ATR correction algorithm. All relative intensity ratios were normalized relative to the peak of the band at $2900 \mathrm{~cm}^{-1}$ which is C-H stretching in methyl and methylene groups. 


\subsection{XPS spectroscopy analysis}

Small wood chips (approximately $10 \times 10$ on exposed surface and $1 \mathrm{~mm}$ width) were cut with a cutter blade from heat-treated and untreated jack pine surfaces before and after artificial sunlight radiation of $72 \mathrm{~h}$ and $1500 \mathrm{~h}$. All preparations were carried out avoiding all contact with bare hands, and the samples were immediately placed in the vacuum plastic bags. The XPS measurements were performed on AXIS Ultra XPS spectrometer (Kratos Analytical) at the Alberta Centre for Surface Engineering and Science (ACSES), University of Alberta. The base pressure in the analytical chamber was lower than 2 x 10-8 Pa. Monochromated $\mathrm{Al} \mathrm{K \alpha}(\mathrm{h} v=1486.6 \mathrm{eV})$ source was used at a power of $210 \mathrm{~W}$. The resolution function of the instrument for the source in hybrid lens mode was $0.55 \mathrm{eV}$ for $\mathrm{Ag}$ 3d and $0.70 \mathrm{eV}$ for $\mathrm{Au} 4 \mathrm{f}$ peaks. The photoelectron exit was along the normal of the sample surface. The analysis spot was $400 \times 700 \mathrm{um}$. Charge neutralizer was used to compensate for sample charging during the analysis. The survey scans spanned from 1100 to $0 \mathrm{eV}$ binding energy, they were collected with analyzer pass energy (PE) of 160 $\mathrm{eV}$ and a step of $0.35 \mathrm{eV}$. For the high-resolution spectra, the pass-energy of $20 \mathrm{eV}$ with a step of $0.1 \mathrm{eV}$ was used. CASA software was utilized in the data processing. A linear background was subtracted from each peak, than the peak area was evaluated and scaled to the instrument sensitivity factors. The composition was calculated from the survey spectra with sum of all peaks after scaling equal to $100 \%$. The spectra fitting and component analysis were performed using the high-resolution spectra. The number of components and their binding-energy positions (shown in Table 1 below) were taken from the paper of Inari et al [37].

\subsection{Scanning electron microscopy (SEM) analysis}

Scanning electron microscopy (SEM) analysis was used to study the microscopic structural changes in heat-treated wood occurring during sunlight irradiation. Small wood blocks measuring $20 \times 20 \mathrm{~mm}$ on the weathered tangential face were cut from heat-treated and untreated boards after artificial sunlight irradiation of different times (0, 336, 672 and 1512 hours). For subsurface cell degradation analysis, same blocks measuring $20 \times 10 \mathrm{~mm}$ on the transverse face and radial face were used. The specimens were immerged in water for 30 minutes and then cut with a razor blade mounted onto a microtome by carefully cutting one of the end-grain surfaces and one radial surface. A new razor blade was used for each final cut. Another method is to split wood samples. However, these surfaces are rough and they usually do not allow observation of the cell lumen. The specimens were washed in distilled water to remove the bleaching agent and then air-dried at room temperature more than two nights and desiccated with 
phosphorus pentoxide for 10 days. Finally, all blocks were sputter coated with a palladium/gold layer (20 nm) and then mounted onto standard aluminum stubs using electrically conducting paste. The samples were scanned using a Jeol scanning electron microscope (JSM 6480LV) with magnification up to $300000 \times$ at $10 \mathrm{kV}$ of accelerating voltage. The distance between sample and electron microscope head was $20-25 \mathrm{~mm}$ with spot size of 35 . The specimen temperature was approximately $20^{\circ} \mathrm{C}$ and the column vacuum was $6.66 * 104 \mathrm{~Pa}$. Digital images were transferred to a personal computer and saved as image files. To improve image quality, resolution, contrast and brightness were corrected digitally on the computer. Electron micrographs were taken for UV irradiated longitudinal tangential surface for different exposure times. SEM micrographs of longitudinal radial surfaces were also taken to observe the cell damage from radial direction.

\section{Results and discussion}

\subsection{Visual observation of surface appearance (Macroscopic structural changes )}

Figure 1 (a, b, c) depicts the color changes and physical changes on radial and tangential surfaces of heat-treated and untreated jack pine during artificial sunlight irradiation. It can be observed from these pictures that the color of both heat-treated and untreated jack pine became lighter and whiter with the increasing exposure time. The final colors of these specimens obtained under three sets of experimental conditions were similar. The visual inspection showed that the radial surfaces of heat-treated wood were smooth and remained without cracks even after artificial sunlight irradiation of $1500 \mathrm{~h}$ (Fig. 1 (a)). On the other hand, minor cracks started to appear on the tangential surface of treated specimens after accelerated sunlight exposure of $672 \mathrm{~h}$ (shown with arrows in Fig. 1 (b)). Visible cracks were clearly observed on the tangential surfaces of the untreated specimens after exposure of $1500 \mathrm{~h}$ while there was no crack appeared on radial part of sample surface at all exposure times. These results indicate that the development of cracks due to sunlight irradiation degradation was more significant on tangential surfaces than on radial surfaces for both heat-treated and untreated jack pine. This phenomenon is probably due to the swelling and shrinking stresses limit produced by the rays on radial surface during artificial sunlight irradiation (I DO NOT UNDERSTAND THIS SENTENCE) . Compared to untreated specimen, after irradiating for $1500 \mathrm{~h}$ (see Fig. 1 (c)), the heat-treated boards retained their physical aspect better, and it is clear that their surface was smoother and had fewer cracks as shown in Figure $1(\mathrm{a}, \mathrm{b})$. This result agrees with the previous study of Manoj and his co-workers 
[21]. They reported that no surface checks were observed on the weathered surfaces of oil heat-treated specimens and the percent swelling after weathering in treated specimens was less than that of untreated wood.

\subsection{Microscopic structural changes}

Microscopic structural changes accompany other physical changes of wood surface taking place during irradiation. A series of papers reported changes in untreated wood surfaces after outdoor exposure as explained below. Heat treatment also changes properties of wood surfaces. During this study, the scanning electron microscope (SEM) was used to investigate the breakdown of heat-treated jack pine wood structure caused by artificial sunlight irradiation. Wood surfaces, both heat-treated and untreated, were investigated. SEM analysis of the transverse and longitudinal surfaces of heat-treated jack pine wood clearly showed the micro-structural changes occurring during sunlight irradiation (see Figs. 2-6) as explained below.

\subsubsection{Degradation of middle lamellar}

From the comparable features on the transverse surfaces of jack pine before and after heat treatment, it can be seen that the structural changes of cell wall took place after heat treatment of jack pine as shown in Figs. 2 (a) and (b). Heat-treated jack pine wood became more brittle than untreated wood. However, structural changes due to heat treatment were not distinct and it was very likely that plasticization of cell wall material occurred only to a very limited degree during heat treatment. The photo degradation took place preferentially in the middle lamella and primary wall for both heat-treated and untreated jack pine samples. This phenomenon was particularly noticeable at the corners of the middle lamella shown in micrograph of the untreated jack pine transverse surface after exposure of 1500 h (see Fig.2 (c)). Heat-treated wood transverse surface showed similar degradation (see Figure 2 (d)). Both untreated and heat-treated wood degraded severely at the middle lamella when subjected to artificial sunlight irradiation. As it is reported in the literature [38], the middle lamella and primary wall are mainly composed of lignin (84\%) with lesser amounts of hemicelluloses (13.3\%) and even less cellulose (0.7\%). The concentration and content of hemicellulose were higher in the secondary wall than those in the middle lamella and primary wall[38]. The sever degradation in middle lamella after sunlight irradiation indicated that lignin was more photosensitive than other composites in wood cell wall. In addition, the heat-treated wood degraded more severely at the secondary wall than untreated wood due to artificial sunlight irradiation (see Fig. 2 (c) and (d)). This can be explained with degradation of hemicelluloses [19] content of the secondary cell wall, which already has low cellulose content 
compared to that of untreated wood (see Fig. 2 (b)), due to heat treatment. Consequently, the percentage of lignin was increased.

Analysis of Figures 3 (a) and (b) indicated that anatomical structure of jack pine was only slightly affected during heat treatment. Fibers and tracheids around the resin channel were still obvious after heat treatment. The main differences were presence of important quantities of extractives deposited in the resins channels, which disappeared after heat treatment (see Fig. 3 (b)). This results were in agreement with the previous research [37]. The artificial sunlight irradiation induced the degradation of cells around the resin channels (see the arrow in Fig.3 (c)), which was caused by differential dimensional changes between the ray cells of resin channels and surrounding wood cells during artificial sunlight irradiation.

\subsubsection{Checking of cell wall}

SEM micrographs of the tracheids on tangential surfaces of untreated and heat-treated jack pine latewood revealed the formation of different patterns of cell wall micro-cracks due to heat treatment and artificial sunlight irradiation. The lumen of tracheids of untreated jack pine was attached to some warty membrane inside the S3 layer (see arrows in Fig. 4(a)), which disappeared in the lumen of heat-treated wood tracheids cell walls (see Fig. 4(b)). Small cracks were observed in some areas on the tracheid cell wall after heat treatment (see arrows in Fig. 4(b)). Micrographs of tangential surface of heat-treated wood also showed the degradation of lignin during artificial sunlight irradiation (see Fig. 4 (c) and (d)). After artificial sunlight irradiation for 672 h, longitudinal micro-cracks which extend aligned with the fibril orientation and diagonal to the fibre axis of the tracheid, diagonal micro-cracks originating from pits, and zone of decay on tangential surface of heat-treated wood (see Fig. 4(c)) were observed. The micro-cracks developed and enlarged principally as a result of contraction in cell walls caused by the moisture during the extended irradiation exposure. It seems that the binding of cellulose microfibrils in the various cell wall layers by lignin has been degraded after artificial sunlight irradiation for $1500 \mathrm{~h}$. Consequently, a separation between two adjacent cells occurred and tracheids loosened, collapsed and became detached from the substrate of wood (see Fig. $4(\mathrm{~d}))$.

The checking of heat-treated jack pine wood surface during sunlight irradiation was different depending on different part and different direction of wood grain. Tree species add one growth increment or ring to their diameter each year, and this ring shows two distinct periods of growth, called earlywood (springwood) and latewood 
(summerwood). Latewood is denser, harder, smother, and darker than earlywood, and its cells have thicker walls and smaller diameters [39]. Checks in this text refer to the macroscopic checks on wood surface which can be observed visually while micro-checks refer to microscopic intercellular and intracellular cracks.

Figures 5 (a) and (b) show the SEM micrographs of radial and tangential surfaces of heat-treated jack pine irradiated for $1500 \mathrm{~h}$. The comparison of both surfaces revealed the difference in micro-cracks featured on both surfaces. A large number of small longitudinal and transversal micro-cracks were observed from the micrographs on tangential surface. In contrast, the existence of large longitudinal micro-cracks along the earlywood/ latewood interface can be observed on the radial surface. Larger number of cells becomes detached from the earlywood bands on the radial surface of heat-treated wood compared to those of latewood. The different degradation behaviors were observed for earlywood and laterwood of heat-treated jack pine and shown in Figures 5 (c) and (d). Abundant uniseriates and diagonal micro-checks occurred on longitudinal tangential surface of heat-treated earlywood after irradiation for 336 h, and all ray cells had disappeared from the surfaces of weathered wood, consequently, only cavities remained (see Fig.5(c)). However, no transverse micro-cracks were observed on earlywood surface. In contrast, no diagonal microchecks of cell wall were observed on the surface of latewood (see Fig.5 (d)) even after irradiation of $1500 \mathrm{~h}$. However, large longitudinal micro-cracks originating from the degradation of ray cells, transverse micro-cracks caused by the break of microfibril (see big arrows in Fig. 5 (d)), many pit structures coalesce (see small arrow), and

deep crevasses in the cross field were formed. The different behavior of structural changes might be related to the chemical differences between earlywood and latewood. Ealywood contains more lignin and less cellulose compared to those of latewood [40].

\subsubsection{Destruction of bordered pits}

Figure 6 shows the SEM micrographs of bordered pits of jack pine tracheids. Heat treatment did not cause damage to the bordered pits (see Fig. 6(b)). It seems that the pit borders on the irradiated side were destroyed and the halfbordered structure on the contrast side was left and became thinner with irradiation as shown in Figure 6 (c). Microcracks on pit borders transverse to cell axis formed while no longitudinal micro-crack across pits was observed on the heat-treated jack pine surface after irradiation for $1500 \mathrm{~h}$. This may be explained with the changes of fibril orientation on the border of pits. The cells were separated from one another, and complete degradation of the middle lamella was evident which indicates the delamination of cells. 
3.3 Color changes during artificial sunlight irradiation up to $1500 \mathrm{~h}$

Figure 7 shows the plots of the extension in redness $\left(a^{*}\right)$ and yellowness $\left(b^{*}\right)$, lightness $\left(\mathrm{L}^{*}\right)$ and the total color difference $(\Delta \mathrm{E})$ of heat-treated and untreated jack pine as a function of artificial sunlight irradiation exposure time. Decrease in a* values indicates a tendency of wood surface to become greener while increase points out a tendency to become redder. The rate of change of a*values represents the rate of wood redness change. During early times of irradiation, a*value of untreated wood increased significantly with irradiation exposure up to $72 \mathrm{~h}$ while those of heat-treated wood decreased significantly on both radial and tangential surfaces. Then the a*values of both heattreated (on both radial and tangential surfaces) and untreated wood reached to almost the same end value with irradiation time up to $336 \mathrm{~h}$, subsequently decreased rapidly after irradiation for $672 \mathrm{~h}$, followed by a decrease with slower rate up to $1500 \mathrm{~h}$. The red-green tint levels of heat-treated and untreated wood were mainly the same after irradiation of $672 \mathrm{~h}, 1008 \mathrm{~h}$ as well as $1500 \mathrm{~h}$, respectively.

Decrease of $b^{*}$ values indicates a tendency of wood surface to become bluer while increase of $b^{*}$ values means a tendency to become yellower. As shown in Figure 7 (b), the trend observed for the b*value changes of heat-treated wood on both radial and tangential surfaces due to artificial sunlight irradiation is similar to that of $\mathrm{a}^{*}$ value, decreasing significantly at the beginning, later remaining the same for certain time, and then decreasing rapidly followed by a decrease at slower rate. The $b^{*}$ value of untreated wood stayed constant with irradiation time up to $168 \mathrm{~h}$, and then decreased quickly up to $672 \mathrm{~h}$, next the decrease rate was reduced. After artificial sunlight irradiation for $168 \mathrm{~h}$, the change tendencies of $\mathrm{b}^{*}$ value for the three wood surfaces were almost the same. The color of both heat-treated and untreated jack pine surface became yellower during exposure to irradiation.

As shown by the changes in $\mathrm{L}^{*}$ values, brightening and darkening of wood surface were observed. Fig.7 (c) shows $L^{*}$ plotted as a function of the exposure time for heat-treated and untreated jack pine. $L^{*}$ was the most sensitive parameter for the wood surface quality during artificial sunlight irradiation. Similar to a*value, $L^{*}$ value displayed different trends for heat-treated and untreated jack pine at earlier times of irradiation, whereas the trends observed for radial and tangential surfaces of heat-treated wood were similar. For untreated wood, L* decreased to a minimum value up to irradiation time of $72 \mathrm{~h}$, then it increased at different rate during extended artificial irradiation. This implied that untreated wood became darker when exposed to sunlight for $72 \mathrm{~h}$ and after became lighter as the irradiation time increased. It was demonstrated that darkening of untreated wood at first stage of artificial sunlight irradiation was mainly due to the migration of extractives to wood surface due to exposure to high temperature 
during the test. Several previous studies reported similar result of darkening of untreated wood surface depending on different artificial sunlight exposure time and type of wood species[5, 21, 27, 28]. The lightening of heat-treated wood increased at the first irradiation stage of $72 \mathrm{~h}$, later stayed more or less stable up to $168 \mathrm{~h}$, after increased with increasing times of exposure until the end of the test. This matched with the lightness result of untreated wood. Extractives of heat-treated wood have been degraded and removed during high temperature heat treatment. Thus, changes in lightness of heat-treated wood with increasing time of artificial sunlight irradiation were mainly due to the lignin photodegradation, and became lighter starting from the beginning of irradiation. After irradiation of 1500 h, similar to the tendencies observed for redness $\left(a^{*}\right)$ and yellowness $\left(b^{*}\right)$, the lightness levels of heat-treated and untreated wood were mainly the same. This indicated that the final colors of untreated and heat-treated jack pine after artificial sunlight irradiation for $1500 \mathrm{~h}$ became unified.

Figure 7 (d) presents the total color differences $(\Delta E)$ for heat-treated and untreated specimens during the artificial sunlight irradiation test. The color on radial and tangential surfaces of heat-treated wood was almost the same. It can be observed that the color of heat-treated jack pine changed more significantly than that of untreated wood at all times during artificial sunlight irradiation. This result disagreed with the results of several previous investigations on the color change of heat-treated and untreated wood [1, 21, 23, 25, 27]. Ayadi and his co-workers reported that the color difference for ash, beech, maritime pine and poplar heartwood, heat-treated under nitrogen, was less during the $835 \mathrm{~h}$ of UV-light exposure when compared to that of untreated wood[25]. They attributed the better resistance of retified wood to light to the less attack on lignin. But they did not show the details of color tint change such as lightness, therefore, it is difficult to compare their results with the results of the present work. It was reported that the color of heat-treated Scots pine changed less than that of untreated wood during artificial weathering experiment [27].Thermal modification of spruce wood was found to be effective in stabilizing color during long term artificial UV light exposure [28]. Manoj and his colleagues found that oil heat treatment can improve Radiata Pinewood color stability, and this was attributed to a protective oil layer on the wood surfaces [21]. It was also reported that color of heat-treated okan sapwood changed less compared to the color change observed for the same species before treatment. [23].

Lightness was the most sensitive parameter for the wood surface quality during sunlight irradiation. The total color change depends mainly on the changes in lightness. In the view of the studies mentioned above, the lightness of untreated woods decreased and then increased whiles those of heat-treated wood increased at different irradiation 
stages. The tendency of color change of heat-treated wood during weathering experiments depended on artificial weathering conditions, type of wood species, and heat treatment techniques and conditions. It was shown that the color change trends of both heat-treated and untreated jack pine specimens used in this study were similar after $72 \mathrm{~h}$ resulting in relatively close final colors after irradiation for 1500 h (see Figure7 (a-c)). As shown in Fig. 8, it can be observed that the color difference between heat-treated and untreated woods at the same artificial irradiation stage reduced rapidly at the beginning of irradiation $(72 \mathrm{~h}$ ), later remained mainly the same up to $1008 \mathrm{~h}$, finally decreased to a value of 1.4 after $1500 \mathrm{~h}$. According to Yoshimoto et al.[41], the above values of color difference between heattreated and untreated samples after artificial sunlight irradiation exposure of $1500 \mathrm{~h}$, are significant and visible to the naked eye. It is possible to perceive differences of about 3.8 units of $\Delta \mathrm{E}^{*}[5,27]$. Thus, the difference of $\Delta \mathrm{E}$ between heat-treated and untreated wood surfaces during artificial sunlight irradiation was due to the difference in their initial colors. The color of both untreated and heat-treated specimens changed to white and gray at the end of the irradiation; however, the original color of heat-treated wood was darker than that of untreated wood before irradiation. The color of wood surface was related to the different wood composites depending on type of wood species and wood treatment methods used. The decrease in lightness and the increase in the color difference of heattreated wood were caused by a decrease in hemicelluloses content, especially pentosan [42]. It was reported that thermal treatment at high temperature degraded cellulose, hemicelluloses[43] and extractives [44]. Kollman and Fengel reported that heat treatment caused a lignin condensation[43]. Photo-discoloration of untreated wood was mainly due to chromophores formed from the photodegradation of lignin and degradation and leaching away of extractives during weathering. Extractives have antioxidant properties and can limit wood color change to light[25].

In the view of these results, the lower color stability of heat-treated jack pine was estimated to be due to increase in lignin condensation and decrease in extractives caused by heat treatment. Consequently, the heat-treated wood surface had reduced antioxidant properties attributed to lower extractive content and its color changed more than that of untreated wood during artificial sunlight irradiation.

\subsection{Wettability changes}

The information of wettability of wood surface by water is useful in understanding the weathering mechanism of heat-treated jack pine. During this study, the dynamic wettability of sample surfaces which were exposed to artificial sunlight radiation for different times was recorded and compared with that of non irradiated (non weathered) samples. The effect of the sunlight irradiation on dynamic contact angle with water, consequently, on the 
wetting properties of heat-treated jack pine was investigated. Furthermore, the effects of heat treatment on the wettability were also studied.

Fig.s 10 (a) and (b) present dynamic contact angle of wood/water system as a function of time for untreated and heat-treated jack pine tangential surfaces, respectively. In these figures, the contact angle evolution with time was given for a non irradiated specimen (irradiation time of $0 \mathrm{~h}$ ) as well as for specimens after artificial sunlight irradiation for 72 hand $1512 \mathrm{~h}$. As it can be seen in both figures, the sunlight irradiation reduced the hydrophobic behavior of both untreated and heat-treated woods; consequently, all the contact angles of weathered wood were lower than those of non irradiated wood. This shows that the artificial sunlight irradiation increased the wettability of wood by water. Contact angles of untreated and heat-treated samples after irradiation reduced with increasing irradiation time at different extents. All dynamic contact angles of heat-treated sample before irradiation were higher than those of untreated sample. On the contrary, the contact angles for heat-treated sample after irradiation for $72 \mathrm{~h}$ were lower considerably than those of untreated sample due to the different effect of artificial sunlight irradiation on heat-treated and untreated wood surfaces. The contact angles of untreated and heat-treated jack pine did not seem to differ significantly after irradiation for $1500 \mathrm{~h}$, and water was absorbed by both woods within one second.

The difference in wood surface structure can cause wettability differences between wood surfaces [45, 46]. SEM analysis indicated that anatomical structure of samples was only slightly affected during heat treatment, whereas dynamic contact angles increased significantly after heat treatment. This implied that the structural factors did not play an important role on wettability while the chemical changes of wood surfaces had more significant effect on the wettability changes during heat treatment. As it was stated before, sunlight irradiation changes heat-treated wood structural properties (Figs. 2-6). SEM analysis suggested that the changes occurring due to sunlight irradiation in the wettability of heat-treated samples tested in this study might be attributed to the surface structural changes. The wettability of wood surface by water was related to the water flow into wood cell lumena and diffusion within the cell wall[47]. Micro-cracks presented on heat-treated sample surfaces after artificial sunlight irradiation (shown in Fig. 4 (c), (d) and Fig. 5) allowed easier entrance of water into cell lumena and cell wall, which consequently decreased contact angles and increased wettability (shown in Fig. 9 (b)). This effect of sunlight irradiation on wettability was different for heat-treated and untreated samples after artificial sunlight irradiation exposure of $72 \mathrm{~h}$. There was no evidence observed that the differences in contact angles of heat-treated and untreated wood after this 
time was related to their structural properties. In addition, the contact angles of the both heat-treated and untreated woods after irradiation for $1500 \mathrm{~h}$ were relatively close, which indicated the structural differences on different wood surfaces at this irradiation stage do not have any significant effect on wettability. Additional information of structural changes found in SEM micrographs on transverse surface of specimens can demonstrate the evolution of water wettability on heat-treated samples during artificial sunlight irradiation (see Fig.2). As it was stated above, because the lignin concentration was the highest in the middle lamella, the weather degradation occurs preferentially in this area. This is noticeable in Fig.s 2 (c) and (d). The degradation of the middle lamella resulted in the separation of adjoined cells, which allowed easier entrance of water into wood. Furthermore, the loss of lignin made the surface more hydrophilic.

Weathering induces changes not only in physical properties of a wood surface but also in its chemical properties [48, 49]. The increase in wettability during weathering can also be related to chemical changes of wood surface [45, 50, 51]. It is well known that heat treatment can cause chemical changes such as degradation of hemicelluloses and extractives, leading to increase in crystallinity and percentage of lignin, consequently, results in an decrease of wettability [52].

\subsection{Chemical changes}

\subsubsection{FTIR analysis}

In this study, the results of the infrared study of artificial sunlight irradiation on heat-treated samples were presented and compared with those of untreated samples in order to investigate the chemical mechanism details. The most representative FTIR bands studied within the spectral range of $4000-550 \mathrm{~cm}^{-1}$ were summarized in Table 2 . Fig. 10 shows the FTIR spectra between the spectral region of $1800-750 \mathrm{~cm}^{-1}$ on untreated jack pine before irradiation and heat-treated samples irradiated with artificial sunlight for different periods. Differences due to heat treatment and light irradiation can be clearly seen in the infrared spectra in the band shapes.

The spectra differences between heat-treated and untreated woods have to be taken into consideration. The top two spectra in Fig.10 shows uniquely different infrared spectra for untreated and heat-treated jack pine before irradiation, respectively, although their infrared spectra in the studied region had some similar features. Upon analysis of the spectra, it can be seen that the relative intensity of band at $1740 \mathrm{~cm}^{-1}$ which was characteristic of non-conjugated carbonyl group stretching in xylan in hemicelluloses, decreased slightly after heat treatment, whereas the relative 
intensity at $1510 \mathrm{~cm}^{-1}$ which was assigned to lignin was not significantly affected by heat treatment. This degradation of hemicelluloses can consequently cause a decrease in water absorption. This can be confirmed by the lower relative intensity on heat-treated sample surface of band at $1650 \mathrm{~cm}^{-1}$ which may refer to adsorbed water. Another peak which has to be taken into consideration was the decrease in the peak at $1230 \mathrm{~cm}^{-1}$ which was characteristic of syringyl nuclei[53] after heat treatment. This indicated that degradation of lignin also occurs during heat treatment.

It was clearly apparent from the results of IR analysis that irradiation had a significant effect on the functional groups found on the heat-treated wood surfaces. Absorption intensities of certain absorption bands changed after irradiation for $72 \mathrm{~h}$. A general observation that can be made from the results was that, the effect of irradiation on untreated and heat-treated samples might be very similar in the long term of irradiation. Light irradiation degradation of heat-treated wood samples caused mainly changes in the absorption intensity at the peaks shown in Fig. 10. The changes in these bands were related to changes in chemical composition of the functional groups and chemical structure of wood components listed in Table 2. As shown in Table 2, all the bands at $1600 \mathrm{~cm}^{-1}, 1510 \mathrm{~cm}^{-}$ 1, $1457 \mathrm{~cm}^{-1}, 1426 \mathrm{~cm}^{-1}, 1267 \mathrm{~cm}^{-1}, 1103 \mathrm{~cm}^{-1}$ and $806 \mathrm{~cm}^{-1}$ represented lignin characteristics. As shown in Fig. 10, all these characteristic bands of lignin decreased at different extents as a result of artificial sunlight irradiation of heat-treated jack pine sample. The peak at $1510 \mathrm{~cm}^{-1}$ was mainly characteristic absorption of $\mathrm{C}=\mathrm{C}$ in an aromatic ring that originated from lignin in wood. It can be observed that the peak at $1510 \mathrm{~cm}^{-1}$ disappeared after irradiation for $72 \mathrm{~h}$. This was in agreement with previous study on untreated wood reported by Pandey[54]. The intensities of peaks at 1373 and $896 \mathrm{~cm}^{-1}$ which were mainly due to carbohydrates (cellulose and hemicelluloses) and had no significant contribution from lignin, were not affected significantly by irradiation. Moreover, the intensity of 1158 $\mathrm{cm}^{-1}$ band increased upon prolonged exposure indicating that lignin was the component of heat-treated wood which was most degraded during irradiation. As a result of this significant photochemical degradation of lignin by irradiation, Erin et al. [55] reported that new bands at 1730 and $1650 \mathrm{~cm}^{-1}$, which may be due to the formation of unconjugated free carbonyl groups and quinines, and quinine methides ( responsible yellowing of wood surface) were generated and changed during different artificial weathering conditions. However, as Fig. 10 shows, the new bands at $1730 \mathrm{~cm}^{-1}$ and $1650 \mathrm{~cm}^{-1}$ were not detected in the present study with heat-treated wood surface during irradiation. 
In order to determine rate of lignin degradation and non-conjugated carbonyl groups content, the intensities of the carbonyl absorption band at $1740 \mathrm{~cm}^{-1}$, lignin reference band at $1510 \mathrm{~cm}^{-1}$ and carbohydrate reference bands at 1375 $\mathrm{cm}^{-1}$ were measured as suggested in literature [56]. The relative change in ratio of lignin/carbohydrate peaks at different irradiation times was calculated by determining the ratio of lignin reference band at $1510 \mathrm{~cm}^{-1}$ against carbohydrate reference bands. As stated above, irradiation degradation had no significant effect on the intensity of bands at $1375 \mathrm{~cm}^{-1}$, this carbohydrate band was used as internal reference for calculating lignin loss due to light irradiation. The relative changes in the lignin/carbohydrate ratio $\left(\mathrm{I}_{1510} / \mathrm{I}_{1375}\right)$ at different irradiation periods for both heat-treated and untreated samples were plotted in Fig. 11 (a). The lignin/carbohydrate ratio decreased rapidly with increasing irradiation time. Lignin of both heat-treated and untreated jack pine samples decreased faster in the beginning of the irradiation test. The relative intensity of lignin aromatic band at $1510 \mathrm{~cm}^{-1}$ decreased to $65 \%$ of its original value after irradiation of $72 \mathrm{~h}$ for heat-treated sample, whereas it became $84 \%$ of its original value for untreated wood for same irradiation time (see Fig. 11(a)). The rate of change of lignin/carbohydrate ratio of heattreated wood was very high at short irradiation time up to $72 \mathrm{~h}$. A significant decrease in the intensity ratio of lignin/carbohydrate peak intensity showed rapid lignin degradation even at beginning of irradiation for heat-treated wood. The slope of the curve changes significantly after $72 \mathrm{~h}$ irradiation exposure and the rate of change of lignin/carbohydrate ratio became very small at intermediate irradiation times. Then, its degrading rate increased at longer irradiation times. The lignin/carbohydrate ratios of heat-treated samples were higher than those of untreated ones after irradiation of same times during all the tests. Lignin of heat-treated jack pine samples degraded at a faster rate than that of untreated samples. After $1500 \mathrm{~h}$ of irradiation, lignin/carbohydrate ratios of both woods were relatively close. This indicated that long period sunlight irradiation decreased the differences in chemical characteristics of heat-treated and untreated wood surfaces, which supported the microstructural and wettability findings stated above.

The proportion of carbonyl groups during irradiation was calculated by taking ratio of intensity of carbonyl band at $1740 \mathrm{~cm}^{-1}$ against carbohydrates peaks at $1375 \mathrm{~cm}^{-1}$. The ratio of intensity of $\mathrm{C}=\mathrm{O}$ band at $1740 \mathrm{~cm}^{-1}$ against 1375 $\mathrm{cm}^{-1}$ band represents the relative changes of carbonyl groups due to light irradiation. The relative changes in the ratio of carbonyl peak at $1740 \mathrm{~cm}^{-1}$ ( $\left.\mathrm{I}_{\text {carbonyl }}\right)$ against carbohydrates peaks at $1375 \mathrm{~cm}^{-1}$ (I carbohydrates $)$ for heat-treated and untreated jack pine as a function of irradiation time were plotted in Fig. 11 (b). The $\mathrm{I}_{1740} / \mathrm{I}_{1375}$ of both woods decreased during irradiation test. Thus, the above results indicated that the unconjugated carbonyl group at $1740 \mathrm{~cm}^{-}$ 
${ }^{1}$ was decreased. This is in agreement with the finding reported by Masanori and Tokato[5]. They found that the unconjugated carbonyl group at $1740 \mathrm{~cm}^{-1}$ decreased with exposure more than $50 \mathrm{~h}$ for untreated tropical wood. However, Pandey [56] observed that the relative concentration of carbonyl groups increased with irradiation time for chir pine and rubber wood. These different findings might be due to the different wood species.

Pandey [56] reported that the color changes at wood surfaces were mainly due to the formation of $\mathrm{C}=\mathrm{O}$ groups due to photodegradation of lignin. Fig. 12 shows the relationship of the color changes ( $\mathrm{L}^{*}, \Delta \mathrm{E}$, and $\left.\mathrm{b}^{*}\right)$ of heat-treated and untreated wood surfaces with the lignin decay and relative intensity of carbonyl absorption peak at $1740 \mathrm{~cm}^{-1}$. As can be seen from Fig.12 (a), the lightness of heat-treated samples increased linearly with the degradation of lignin, whereas for untreated samples, the lightness also increased when irradiated more than $168 \mathrm{~h}$ but was not linearly related to the lignin decay. This might be explained with the increasing amount of extractives coming from the interior of untreated wood substance to wood surface during first period of irradiation, consequently, reducing the surface lightness. The dependence of total color changes to loss of lignin on heat-treated wood surfaces was more than that of untreated wood (see Fig. 12(b)). In the view of these findings, the wood color changes were related to combination of changes in lignin and extractives contents during light irradiation. Pandey[56] also reported that color differences of chir pin and rubber wood during irradiation correlated linearly with the formation of the nonconjugated carbonyl functionality $\left(\mathrm{I}_{1735} / \mathrm{I}_{1375}\right)$, increasing as a function of irradiation time. The results of Masanori and Tokato[5] suggested that the formation of non-conjugated carbonyl functionality played an important role in the color change in woods for which $\Delta b^{*}$ increased but not for woods of which $\Delta b^{*}$ decreased. However, it can be observed from the color results showed in Fig. 7 (b) and Fig. 11(b) that the $\Delta b^{*}$ and the non-conjugated carbonyl function $\left(\mathrm{I}_{1740} / \mathrm{I}_{1375}\right)$ of both heat-treated and untreated jack pine surfaces decreased due to irradiation, and the relative changes in non-conjugated carbonyl function $\left(\mathrm{I}_{1740} / \mathrm{I}_{1375}\right)$ followed inverse relationship with $\mathrm{b}$ *(see Fig.12(c)). Thus, it was possible to obtain a correlation of b* and carbonyl groups content $\left(\mathrm{I}_{1740} / \mathrm{I}_{1375}\right)($ See Fig.12(c)). The question was raised as to why the non-conjugated carbonyl function of our samples did not increase, which was supposed to be formed by the degradation reaction of lignin during light irradiation.

The ratio of peak heights at 1429 and $897 \mathrm{~cm}^{-1}\left(\mathrm{H}_{1429} / \mathrm{H}_{896}\right)$ of FTIR spectra of wood samples was used for the determination of crystallinity of cellulose in wood samples [59]. In this study, higher $\mathrm{H}_{1429} / \mathrm{H}_{896}$ ratio for heat-treated wood samples was found compared to that of untreated wood samples. It was observed that the $\mathrm{H}_{1429} / \mathrm{H}_{896}$ ratio decreased for both heat-treated and untreated samples during light irradiation as shown in Fig. 13 (a). The results 
indicated that crystalline cellulose was degraded which caused a decrease in the crystallinity of all specimens and degradation occurred at different extents depending on heat treatment. The cell wall is hydroscopic and the order of hydroscopicity for the cell wall polymer is: hemicelluloses, cellulose, and then lignin[57]. The degradation of lignin by light irradiation can increase the content of other components on wood surface and consequently make the surface more hydrophilic. The same observation is reported by Kalnins and Feist[45]. They reported that contact angle on weathered western red cedar dropped after four weeks of outdoor weathering. It was also reported that wettability for Sitka spruce increased when exposed to xenon arc radiation and water spray [58]. The sorption of water by wood depends on the hydrophilic nature of each cell wall polymer and the accessibility of water to the hydroxyl groups of polymer. Most of the hydroxyl sites in the hemicelluloses and lignin are accessible to moisture. The amorphous cellulose (non-crystalline portion of cellulose) and the surfaces of the crystallites are accessible to moisture, but the crystalline part is not. The increase of crystallinity proportion due to degradation of hemicelluloses during heat treatment reduced the water wettability on heat-treated wood. The loss of crystallinity caused by irradiation raised the amorphous portion of cellulose and, consequently, increased the hydrophilic nature of wood surface.

The hydroxyl (-OH) containing groups are hydrophilic groups, while the hydrocarbon chains $\left(-\mathrm{CH}_{2}-\right)$ are hydrophobic groups [45]. The changes of these functional groups can change the wettabilty of wood surface by water. The bands at 3500 and $2900 \mathrm{~cm}^{-1}$ shown in Figure 13(b) refer to hydroxyl groups (-OH) and hydrocarbon chains (- $\left.\mathrm{CH}_{2}-\right)$, respectively $[45,60]$. Fig. 13 (b) showed the $\mathrm{OH} / \mathrm{CH}_{2}$ ratio of heat-treated and untreated jack pine as a function of different light irradiation time. The $\mathrm{OH} / \mathrm{CH}_{2}$ ratios of all samples increased as irradiation time increased up to $72 \mathrm{~h}$ and then changed relatively slightly or stayed almost constant up to $1500 \mathrm{~h}$ as shown in Fig.13 (b). Before irradiation, there were more hydroxyl groups on untreated wood surfaces than those of heat-treated wood; however, after weathering for $1008 \mathrm{~h}$ the opposite was true. This might result in increase in wettability of heat-treated woods by water compared to that of untreated woods after irradiation. However, present study exhibited the contrary dynamic contact angle results after irradiation for $72 \mathrm{~h}$ as shown in Fig. 9. It was demonstrated that the presence of extractives had a significant effect on the wettability of untreated wood surface by water after irradiation for $72 \mathrm{~h}$. Kalnins and Feist[50] proposed that one reason for the wettability increase with weathering might be the reduction or removal of the water repellent effect of extractives. Extractives left wood surface due to irradiation, but they were partially replaced by those migrating towards the surface from the interior of wood substance during 
exposure of irradiation. Extractive content of untreated woods was higher than that of heat-treated woods. Therefore, there was a bigger supply of extractives which can migrate from the interior of the untreated wood compared to that of heat-treated wood during irradiation process. Thus, the quantity of extractives present on untreated wood surfaces was more than that of heat-treated wood surfaces after irradiation. These extractives raised the hydrophobicity of untreated wood surfaces; in other words, increased the contact angles (less wettable) as shown in Fig. 9 (a). As stated above, contact angles of both heat-treated and untreated samples decreased with increasing irradiation time, while $\mathrm{OH} / \mathrm{CH}_{2}$ ratios did not change during all through the irradiation period (see Fig.13 (b)). This indicated that the contact angle was dependent on $\mathrm{OH} / \mathrm{CH}_{2}$ ratios at different extents depending on irradiation time for the specimens tested in this study. Thus, it is probable that factors other than chemical properties, such as structural factors stated above, affect the changes in wettability of the specimens during different irradiation stages.

\subsubsection{XPS analysis}

X-ray photoelectron spectroscopy analysis has been reported as an important technique to characterize wood surface chemical composition in relation with interfacial phenomena[37]. The typical XPS survey spectra of heat-treated and untreated jack pine wood samples before and after artificial sunlight irradiation for $1500 \mathrm{~h}$ were shown in Fig. 14, respectively. Both the spectra of untreated (see Fig. 14 (a) and (b)) and heat-treated samples (see Fig. 14 (c) and (d)) revealed presence of carbon, oxygen and small amounts of nitrogen as expected. It can be seen from the comparison of the survey spectra of samples before and after irradiation that the carbon C1s peak decreased and the oxygen O1s peak increased due to irradiation for both untreated and heat-treated samples. Only these two elements were present to a noticeable amount.

It has been previously reported that the degradation of cellulosic materials and polymers can be detected by a change in the $\mathrm{O} / \mathrm{C}$ atomic ratio[37].Using the total areas of peaks of different components and the respective photoemission cross-sections, $\mathrm{O} / \mathrm{C}$ ratio can be quantitatively determined. The relative distribution of composition of $\mathrm{O}$ and $\mathrm{C}$ atoms and the calculated oxygen to carbon $(\mathrm{O} / \mathrm{C})$ ratio for all samples (heat-treated and untreated) before and after irradiation for different times were presented in Fig.15.

According to the chemical component analysis, untreated jack pine wood contains approximately $29 \%$ lignin, $60 \%$ holocellulose and 6\% extractives. By knowing the chemical composition of each of these components, it is possible to calculate theoretical $\mathrm{O} / \mathrm{C}$ ratio characteristic of wood samples. In principle, cellulose has the gross formula 
$\left(\mathrm{C}_{6} \mathrm{H}_{10} \mathrm{O}_{5}\right)$ and thus the $\mathrm{O} / \mathrm{C}$ ratio is calculated as 0.83 . A lower $\mathrm{O} / \mathrm{C}$ ratio ESCA experimental value of 0.62 of cellulose was reported $[37,61]$ which was explained by possible deposition of hydrocarbon on cellulose surface. Hemicellulose, which is mainly represented by glucuronoxylans, has an $\mathrm{O} / \mathrm{C}$ of approximately 0.8 . The contribution of lignin is more complex and therefore more difficult to calculate. The theoretical value of $\mathrm{O} / \mathrm{C}$ for lignin is around $0.33[37,61]$. Since extractives are also present in very small quantities in jack pine, their contribution to the overall XPS spectrum is relatively low except under certain conditions. A high oxygen carbon atomic ratio $(O / C)$ indicates high cellulose and hemicelluloses contents, while a low O/C ratio reflects higher lignin content on wood surface. The O/C ratios of both heat-treated and untreated samples increased considerably at the initial irradiation time of 72 $\mathrm{h}$ and they kept increasing at a lower rate than the initial rate up to $1500 \mathrm{~h}$ (see Fig. 15). This means that irradiation reduced lignin content, consequently the carbohydrates content increased on both wood surfaces. O/C ratios of both untreated and heat-treated wood after irradiation for $1500 \mathrm{~h}$ were much higher than O/C value of lignin (0.33) and relatively close to the ESCA experimental value of 0.62 of cellulose. This implies that irradiation resulted in wood surfaces richer in cellulose and poorer in lignin. O/C ratio gives a direct measurement of the surface oxygen content, and a high oxygen content normally points to oxidation of the surface.

The changes provoked in wood composition by heat treatment were less compared to those induced by light irradiation at wood surface. Fig.15 shows that $\mathrm{O} / \mathrm{C}$ ratio increased slightly (from 0.25 to 0.28 ) after heat treatment for samples before irradiation. This is not in agreement with the result of study of Sernek [62], which showed that wood drying at high temperature $\left(160^{\circ} \mathrm{C}<\mathrm{T}<180^{\circ} \mathrm{C}\right)$ decreased the oxygen to carbon ratio (O/C) of wood. Nguila and Petrissans also reported that the oxygen to carbon ratio $(\mathrm{O} / \mathrm{C})$ decreased from 0.55 to 0.44 after high temperature treatment of beech wood, and this decrease in O/C ratio appeared to be closely related to carbohydrates (cellulose and hemicelluloses) degradation leading to the formation of volatile by-products with a lower oxygen content resulting from dehydration of polymers initially present in wood[37]. O/C ratio of all heat-treated samples were slight higher than those of untreated samples in this study during irradiation duration, however, this is not enough to suggest that irradiation has less oxidizing and degrading influence on the lignin of the heat-treated sample surface. The high carbon content in wood samples has been reported as an indication of the presence of lignin and extractives on the wood surface [63]. Untreated jack pine wood is rich in carbon-rich extractives (about 6\%) of waxes, fats and terpenes and lignin guaiacyl units' contents [64]. This can be confirmed by the lower oxygen to carbon ratio (0.25) of untreated jack pine comparing to that of other species such as beach wood given in the literature (0.55) [37].The 
increase in $\mathrm{O} / \mathrm{C}$ ratio was probably due to the partial removal of the abundant carbon-rich extractives in jack pine such as fatty acids, terpenes, and phenolics during high temperature heat treatment.

In this analysis, the focus was on the high-resolution of the XPS spectra of C 1s and O 1s levels. Other elements presented lower peaks than the peaks of carbon and oxygen, indicating that they have very low concentrations at the surface of heat-treated and untreated jack pine wood. This is in agreement with the results of Shen et al[65]. The high-resolution of $\mathrm{C} 1 \mathrm{~s}$ and $\mathrm{O} 1 \mathrm{~s}$ were also fitted with their decomposition into four and two components, respectively. According to the literature [37, 63, 65-67], the four peaks in deconvoluted high resolution XPS spectrum of the C1s peaks may appear generally expressed as $\mathrm{C}_{1}-\mathrm{C}_{4}$ and these carbon bands correspond to $\mathrm{C}-\mathrm{C}$ and /or $\mathrm{C}-\mathrm{H}\left(\mathrm{C}_{1}\right), \mathrm{C}-\mathrm{O}\left(\mathrm{C}_{2}\right), \mathrm{C}=\mathrm{O}$ or /and $\mathrm{O}-\mathrm{C}-\mathrm{O}\left(\mathrm{C}_{3}\right)$ and $\mathrm{O}=\mathrm{C}-\mathrm{O}\left(\mathrm{C}_{4}\right)$, respectively, as shown in Table 1 . The results of this study shows that the chemical shifts and binding energies of C1s peaks found in this study are in very good agreement with the literature values for woody materials (Table 1). The high-resolution of the XPS spectra of C1s of sample surfaces before and after irradiation for $1500 \mathrm{~h}$ were detected and shown in Fig. 16. Careful analysis of the line shapes and intensities of each component at irradiated surface showed that the heat-treated wood surface exhibited similar XPS patterns compared to that of untreated wood surface before and after irradiation. However, the XPS patterns changed considerably after irradiation for both untreated and heat-treated wood surfaces. The contribution of $\mathrm{C}_{1}$ and $\mathrm{C}_{2}$ peaks were more important than $\mathrm{C}_{3}$ and $\mathrm{C}_{4}$ peaks, indicating that they have higher concentrations at the all surfaces. These two peaks were also modified by the irradiation process. The detailed analysis of the C1s region for heat-treated and untreated samples showed that the most important contributions for surfaces before irradiation came from the $\mathrm{C}_{1}$ class (see Fig. 16 (a) and (c)), while the most important contributions for irradiated surfaces came from the $C_{2}$ class (see Fig. 16 (b) and (d)). $C_{1}$ peak corresponds to carbon linked to carbon $(\mathrm{C}-\mathrm{C})$ present in lignin, hemicelluloses and extractives, such as the fatty acids, and hydrogen (C-H) groups of lignin and extractives, and $\mathrm{C}_{2}$ peak component corresponds to $\mathrm{OCH}$ groups of lignin and $\mathrm{C}-\mathrm{O}-\mathrm{C}$ linkages of extractives and polysaccharides of wood [37]. It appears that the $\mathrm{C}_{1}$ class is most abundant in wood before irradiation.

Fig. 17 shows the variation in peak area contributions of $C_{1}$ and $C_{2}$ components as a function of irradiation time for both untreated and heat-treated samples. The $C_{1}$ contribution decreased while the $C_{2}$ contribution increased due to irradiation with exposure time for untreated and heat-treated samples. Since cellulose has a much higher contribution from $\mathrm{C}_{2}$ component than lignin and a contribution of the $\mathrm{C}_{1}$ component for cellulose can be considered 
negligible, the $\mathrm{C}_{1}$ component is associated with the presence of lignin on wood surface, and the $\mathrm{C}_{2}$ component is mainly originated from cellulose and hemicelluloses [66]. Similar reasoning can be applied for the O/C ratio. This indicates that the lignin was more sensitive than cellulose against sun light and the content of lignin became less important after irradiation exposure. This change can be partially attributed to an increase of the cellulose content due to preferential degradation of lignin. This indicated that irradiated heat-treated jack pine surface was rich in cellulose and poor in lignin. Similar to the change trend of $\mathrm{C}_{2}$ contribution, a slight increase in the $\mathrm{C}_{3}$ peak was observed (see Fig. 16). This indicates that the percent contribution of the O-C-O linkages in cellulose and hemicelluloses and a lower extend to carbonyl groups $(\mathrm{C}=\mathrm{O})$ rise during irradiation. This proved again the irradiated surface was poor in lignin and comparatively rich in cellulose and hemicelluloses. The $\mathrm{C}_{4}$ peak representing a carbon atom linked to a carbonyl and noncarbonayl oxygen was insignificant in all three samples (only about 5\%). This can be explained by a possible low content of carboxylic groups on the sample surfaces. The analysis of the effect of high temperature treatment on the C1s spectra of jack pine wood surface showed no significant variation. $\mathrm{C}_{1}$ contribution increased slightly (from $64.1 \%$ to $65.4 \%$ ), and $\mathrm{C}_{1}$ contribution reduced insignificantly (from $28.2 \%$ to $27.6 \%$ ). However, the difference increased up to irradiation time of $72 \mathrm{~h}$ and then decreased after. $\mathrm{C}_{1}$ and $\mathrm{C}_{2}$ contribution of heat-treated wood surface changed less compared to that of untreated wood, implying irradiation had less significant influence on the $\mathrm{C}_{1 \mathrm{~s}}$ component change of heat-treated wood surface.

A few researchers studied and analyzed O1s peak of wood-derived materials because of its complex shift behavior compared with the $\mathrm{C} 1 \mathrm{~s}$ peak[66]. The $\mathrm{O}_{1}$ component has a binding energy of $531.6 \pm 0.4 \mathrm{eV}$. It was proposed that this component was associated to lignin[68]. Hua and his co-workers [68] stated that increase in the $\mathrm{O}_{1}$, indicates a decrease in carbohydrates on the fiber surface and an increase in lignin and extractives. It was also observed that eliminating lignin from the fiber surface by high temperature treatment decreased fractional area of $\mathrm{O}_{1}$, and increased that of $\mathrm{O}_{2}[66]$.

Figure 18 shows the O1s spectra of heat-treated jack pine sample studied during irradiation. These illustrations show two components: $\mathrm{O}_{1}$ and $\mathrm{O}_{2}$.The spectra analyses give to $\mathrm{O}_{1}$ and $\mathrm{O}_{2}$ binding energies of $531.6 \pm 0.4 \mathrm{eV}$ and $532.6 \pm$ $0.1 \mathrm{eV}$, respectively. The binding energies of $\mathrm{O}_{1}$ were in an excellent agreement with those reported in the literature with the $\mathrm{O}_{1}$ of woody material $[37,66]$. The binding energy of $\mathrm{O}_{2}$ component value was somewhat lower than that reported for birch and spruce chimicothermomechanical pulps [66]. Its binding energy was similar to that reported by Nguila et al.[37]. 
The fractional areas of the $\mathrm{O}_{1}$ components increased, while $\mathrm{O}_{2}$ components decreased due to heat treatment, which is in agreement with the previous study[66]. The analysis of the effect of irradiation on the O1s spectra showed that the fractional areas of the $\mathrm{O}_{1}$ decreased whereas those of $\mathrm{O}_{2}$ increased for both untreated and heat-treated samples (see Fig.19). Because $\mathrm{O}_{1}$ components is associated with lignin and $\mathrm{O}_{2}$ components with carbohydrate (Table 1 ), it can be said that irradiation decreases the lignin content and increases that of carbohydrate on wood surface. The degradation occurred at the initial duration of irradiation for both woods. After irradiation for $1500 \mathrm{~h}$, the characteristic of $\mathrm{O} 1 \mathrm{~s}$ became similar between heat-treated and untreated samples. The results supported that irradiation degraded wood surfaces and their properties became similar.

The increase of $\mathrm{C}_{1}$ and $\mathrm{O}_{1}$ components after heat treatment suggested that there are differences in the flow of the wood components. Any material should reach a temperature of $60-70^{\circ} \mathrm{C}$ higher than its glass transition temperature to flow. The glass transition temperature of lignin was reported to be $90-110^{\circ} \mathrm{C}[66]$. Consequently, lignin flowed when wood was heat-treated at $210^{\circ} \mathrm{C}$ and passed from a glass state to a rubber state in the presence of moisture. Thus, lignin presence on heat-treated wood surface was abundant. Lignin protected the hydrogen bonds that link adjacent fibres of cellulose from water and moist conditions by its hydrophobic nature. The improvement of wettability of heat-treated wood supported this affirmation (see Fig.9). Lignin may freeze between other components of wood (cellulose and hemicelluloses) and acts as thermoplastic glue after cooling. However, the degradation of heat-treated wood due to irradiation suggests that this phenomenon is not likely to have an effect on lignin protection during long term irradiation.

\subsection{Mechanism}

The combined action of sunlight and humidity results in surface lightening (Fig.1, and Fig. 7(c)) during the weathering of heat-treated wood surface and leads to formation of macroscopic and microscopic cracks or checks (Fig.1, 4, 5, and 6 ). Cells lose bond strength with adjacent cells near the wood surface because of the degradation of lignin deposited in the cell corners and middle lamella (Fig.2). As irradiation continues, humidity washes out degraded by-products present on the wood surface and the exposed surface goes through further degradation (Fig. 7). Thus, a cyclic damage of heat-treated wood surface occurs during the weathering process. Discoloration and checking of heat-treated and untreated wood surface differ in intensity; however, both wood surfaces become increasingly uneven (Fig.1). Changes in wettability during irradiation of heat-treated wood were induced by the combination of structural and chemical changes occurring at the surface. Macro-cracks and micro-cracks form 
during irradiation. This degradation results in easier entrance of water into cell wall of heat-treated wood which consequently increases wood wettability. Lignin is more sensitive to irradiation compared to other wood components; therefore, heat-treated jack pine surface becomes richer in cellulose and poorer in lignin after irradiation. The cellulose-rich layer on wood surface and increasing amorphous cellulose content which is transformed from crystallized cellulose result in increase of free hydroxyl groups, and consequently enhance the wettability on heat-treated wood surface by water (Fig.9).

Lignin is an amorphous three-dimensional natural polymer in which the building units are connected with ether and C-C bonds in a helical structure [69]. In this study, the results showed that the lignin of heat-treated jack pine is degraded due to exposure to artificial sunlight. Based on the experimental and characterizations results, as discussed previously, the following lignin photo-degradation mechanism is proposed. Lignin is degraded by cleavage of C-C bonds, leading to a reduction or elimination of side-chains as confirmed by the reduction of C1 class in XPS spectra. The $\gamma$-C might split from quinone intermediates, releasing formaldehyde. The $\alpha$-carbonyl group of lignin absorbs the radiation energy and is transferred into an excited state [6], which initiates the cleavage of the $\beta$-arylether linkage. After several electron migration steps, quinoid compounds are probably formed, which might be accompanied by a color change [55]. While this happens to untreated wood during the initial irradiation period up to $72 \mathrm{~h}$, it happens to heat-treated wood after $168 \mathrm{~h}$ of irradiation, which can be confirmed by the color results (Fig. 7).

\section{Conclusions}

Heat-treated and untreated jack pine samples were exposed to artificial sunlight irradiation for various periods. The changes in microscopic and chemical structures taking place on heat-treated wood surfaces due to irradiation were analyzed using different analysis methods.

Degradation of middle lamellar, checking of cell wall and destruction of bordered pits occurred due to irradiation on heat-treated wood surface. Photo-degradation occurred preferentially in middle lamella of wood surface where the lignin concentration was the highest in the cell wall. There was no notable difference in surface structure degradation of untreated and heat-treated wood after long term irradiation.

Discoloration of wood was due to combination of the photo-degradation of lignin and extractives on wood surface during irradiation. Further color changes occurring during irradiation of heat-treated jack pine were estimated to be 
due to increase in lignin condensation and decrease in extractives content on wood surfaces caused by heat treatment.

The irradiation increased the wettability of both heat-treated and untreated jack pine woods by water. Heat-treated and untreated wood exhibited different wetting behavior during artificial irradiation due to the differences in contents of extractives and those of other polymer components induced by heat treatment.

\section{Acknowledgements}

The authors thank Fonds québécois de la recherche sur la nature et les technologies (FQRNT), Développement Économique Canada (DEC), Ministère du Développement Économique, de l’Innovation et de l'Exportation (MDEIE), Conférence Régionale des Élus du Saguenay-Lac-St-Jean (CRÉ), Université du Québec à Chicoutimi (UQAC), Fondation de l’Université du Québec à Chicoutimi (FUQAC), FPInnovation, Alberta Innovates, and industrial partners (PCI Ind., Kisis Technology, and Industries ISA), for their technical and financial contributions. We also thank Centre universitaire de recherche sur l'aluminium (Cural) for valuable assistance and technical support during SEM tests as well as the Alberta Centre for Surface Engineering and Science (ACSES) at University of Alberta for technical support during XPS analysis.

\section{Reference}

[1] Nuopponen M, Wikberg H, Vuorinen T, Maunu SL, Jämsä S, Viitaniemi P. Heat-treated softwood exposed to weathering. Journal of Applied Polymer Science. 2004;91:2128-34.

[2] Feist WC, Rowell RM, Barbour RJ. Outdoor wood weathering and protection. Archaeological Wood: Properties, Chemistry, and Preservation. 1990:263-98.

[3] Hon DNS. Photochemistry of wood. Wood and Cellulosic Chemistry. 1991:525-55.

[4] Hon DNS, Minemura N. Color and discoloration. Wood and Cellulosic Chemistry. 2001:385-442.

[5] Kishino M, Nakano T. Artificial weathering of tropical woods. Part 2: Color change. Holzforschung. 2004;58:558-65.

[6] Feist WC, Hon DNS. Chemistry of weathering and protection. The Chemistry of Solid Wood. 1984:401-51.

[7] Lin SY, Kringstad KP. Photosensitive groups in lignin and lignin model compounds. Tappi. 1970;53:658-63.

[8] Miniutti VP. Microscale changes in cell structure at softwood surfaces during weathering. Forest Prod J. 1964;14:571-6. 
[9] Miniutti VP. Microscopic observations of ultraviolet irradiated and weathered softwood surfaces and clear coatings. US Forest Service Research Paper FPL. 1967;74:1-32.

[10] Miniutti VP. CONTRACTION IN SOFTWOOD SURFACES DURING ULTRAVIOLET IRRADIATION AND WEATHERING. J Paint Technol. 1973;45:27-34.

[11] Borgin K, Parameswaran N, Liese W. The effect of aging on the ultrastructure of wood. Wood Science and Technology. 1975;9:87-98.

[12] Evans PD. Structural changes in Pinus radiata during weathering. J Inst Wood Sci. 1989;11:172-81.

[13] Kuo M-L, Hu, N. Ultrastructural changes of photodegradation of wood surfaces exposed to UV. Holzforschung. 1991:45, pp. 347-53.

[14] Owen JA, Owen NL, Feist WC. Scanning electron microscope and infrared studies of weathering in Southern pine. Journal of Molecular Structure. 1993;300:105-14.

[15] Paajanen LM. Structural changes in primed Scots pine and Norway spruce during weathering. Materiaux et constructions. 1994;27:237-44.

[16] Salaita GN, Ma FMS, Parker TC, Hoflund GB. Weathering properties of treated southern yellow pine wood examined by X-ray photoelectron spectroscopy, scanning electron microscopy and physical characterization. Applied Surface Science. 2008;254:3925-34.

[17] Sivonen H, Maunu SL, Sundholm F, Jämsä S, Viitaniemi P. Magnetic resonance studies of thermally modified wood. Holzforschung. 2002;56:648-54.

[18] Kotilainen R, Alén R, Arpiainen V. Changes in the chemical composition of Norway spruce (Picea abies) at 160-260 ${ }^{\circ} \mathrm{C}$ under nitrogen and air atmospheres. Paperi ja Puu/Paper and Timber. 1999;81:384-8.

[19] Syrjänen T, Kangas E. Heat treated timber in Finland. The International Research Group on Wood Preservation, IRG/WP 00-40158, IRG Secretariat. 2000;SE-100:44.

[20] Ahajji A, Diouf PN, Aloui F, Elbakali I, Perrin D, Merlin A, et al. Influence of heat treatment on antioxidant properties and colour stability of beech and spruce wood and their extractives. Wood Science and Technology. 2009;43:69-83.

[21] Dubey MK, Pang S, Walker J. Color and dimensional stability of oil heat-treated radiata pinewood after accelerated UV weathering. Forest Products Journal. 2010;60:453-9.

[22] Mayes D, Oksanen O. Thermo Wood ${ }^{\circledR}$ Handbook. 2002:52. 
[23] Shi Q, Jiang JH. Color stability of heat-treated okan sapwood during artificial weathering. Guilin2011. p. 13-6.

[24] Del Menezzi CHS, de Souza RQ, Thompson RM, Teixeira DE, Okino EYA, da Costa AF. Properties after weathering and decay resistance of a thermally modified wood structural board. International Biodeterioration and Biodegradation. 2008;62:448-54.

[25] Ayadi N, Lejeune F, Charrier F, Charrier B, Merlin A. Color stability of heat-treated wood during artificial weathering. Holz als Roh - und Werkstoff. 2003;61:221-6.

[26] Jämsä S, Ahola P, Viitaniemi P. Long-term natural weathering of coated ThermoWood. Pigment and Resin Technology. 2000;29:68-74.

[27] Temiz A, Terziev N, Jacobsen B, Eikenes M. Weathering, water absorption, and durability of silicon, acetylated, and heat-treated wood. Journal of Applied Polymer Science. 2006;102:4506-13.

[28] Deka M, Humar M, Rep G, Kričej B, Šentjurc M, Petrič M. Effects of UV light irradiation on colour stability of thermally modified, copper ethanolamine treated and non-modified wood: EPR and DRIFT spectroscopic studies. Wood Science and Technology. 2008;42:5-20.

[29] Mitsui K. Changes in the properties of light-irradiated wood with heat treatment: Part 2. Effect of lightirradiation time and wavelength. Holz als Roh - und Werkstoff. 2004;62:23-30.

[30] Letourneau D, Irmoulr M, Krause C, Belloncle C. Colour stability of three different heat treated wood species during artificial weathering. Proceedings of the Second European Conference on Wood Modification. 2005:5760.

[31] Schultz TP. Rapid determination of lignocellulose by diffuse reflectance fourier transform infrared spectrometry. Analytical Chemistry. 1985;57:2867-9.

[32] Hunt RWG. The Reproduction of Color. 1995.

[33] de Moura LF, Hernández RE. Evaluation of varnish coating performance for two surfacing methods on sugar maple wood. Wood and Fiber Science. 2005;37:355-66.

[34] De Moura LF, Hernández RE. Effects of abrasive mineral, grit size and feed speed on the quality of sanded surfaces of sugar maple wood. Wood Science and Technology. 2006;40:517-30.

[35] Hon DNS, Ifju G. Measuring penetration of light into wood by detection of photo-induced free radicals. Wood Sci. 1978;11:118-27. 
[36] Hon DNS. WEATHERING OF WOOD IN STRUCTURAL USE. Blacksburg, Va, USA: Va Polytech Inst, Lab for the Study of Environ Degrad of Eng Mater; 1981. p. 519-29, 8.

[37] Nguila Inari G, Petrissans M, Lambert J, Ehrhardt JJ, Gérardin P. XPS characterization of wood chemical composition after heat-treatment. Surface and Interface Analysis. 2006;38:1336-42.

[38] Rowell RM, Pettersen R, Han JS, Rowell JS, Tshabalala MA. Cell wall chemistry. Handbook of Wood Chemistry and Wood Composites. 2005:35-74.

[39] Williams RS. Handbook of Wood Chemistry and Wood Composites. Weathering of Wood. 2005:139-85.

[40] Fengel D, Wegener G. Chemical composition and analysis of wood. Wood - Chemistry, Iltrastructure, Reactions. 1984:56.

[41] Yoshimoto T, Samejima M. Rengas wood extractives relating to light induced reddening. Mokuzai Gakkaishi. 1977;23:601-4.

[42] Bekhta P, Niemz P. Effect of high temperature on the change in color, dimensional stability and mechanical properties of spruce wood. Holzforschung. 2003;57:539-46.

[43] Kollmann F, Fengel D. Changes in the chemical composition of wood by thermal treatment. Änderungen der chemischen Zusammensetzung von Holz durch thermische Behandlung. 1965;23:461-8.

[44] Avat F. Contribution à l'étude des traitements Thermiques du bois jusqu'à $300{ }^{\circ} \mathrm{C}$ : Transformations chimiques et caractérisations physico-chimiques. Contribution a L'étude des Traitements Thermiques du Bois Jusqu'à 300 ${ }^{\circ} \mathrm{C}$ : Transformations Chimiques et Caracterizationsphysico-Chimiques. 1993.

[45] Kishino M, Nakano T. Artificial weathering of tropical woods. Part 1: Changes in wettability. Holzforschung. 2004;58:552-7.

[46] Patton TC. SIMPLIFIED REVIEW OF ADHESION THEORY BASED ON SURFACE ENERGETICS. Tappi. 1970;53:421-9.

[47] Banks WB. Water uptake by scots pine sapwood, and its restriction by the use of water repellents. Wood Science and Technology. 1973;7:271-84.

[48] Kataoka Y, Kiguchi M. Depth profiling of photo-induced degradation in wood by FT-IR microspectroscopy. Journal of Wood Science. 2001;47:325-7.

[49] Horn BA, Qiu J, Owen NL, Feist WC. FT-IR studies of weathering effects in Western red cedar and Southern pine. Chemical Modification of Lignocellulosics. 1992. 
[50] Kalnins MA, Feist WC. Increase in wettability of wood with weathering. Forest Products Journal. 1993;43:55.

[51] Gindl M, Reiterer A, Sinn G, Stanzl-Tschegg SE. Effects of surface ageing on wettability, surface chemistry, and adhesion of wood. Holz als Roh - und Werkstoff. 2004;62:273-80.

[52] Kocaefe D, Poncsak S, Dore G, Younsi R. Effect of heat treatment on the wettability of white ash and soft maple by water. Einfluss der Wa?rmebehandlung auf die Benetzbarkeit von Weißesche und Rot-Ahorn mit Wasser. 2008;66:355-61.

[53] Colom X, Carrillo F, Nogués F, Garriga P. Structural analysis of photodegraded wood by means of FTIR spectroscopy. Polymer Degradation and Stability. 2003;80:543-9.

[54] Pandey KK. A Study of Chemical Structure of Soft and Hardwood and Wood Polymers by FTIR Spectroscopy. Journal of Applied Polymer Science. 1999;71:1969-75.

[55] Anderson ELP, Zenon1; Owen, Noel L.1; Feist, William C.2. Infrared Studies of Wood Weathering. Part I: Softwoods Society for Applied Spectroscopy. 1991;45:521-714 (May 1991) , pp. 641-647(7).

[56] Pandey KK. Study of the effect of photo-irradiation on the surface chemistry of wood. Polymer Degradation and Stability. 2005;90:9-20.

[57] Skaar C. Wood-water relationships. Chemistry of Solid Wood Adv Chem. 1984;207:127-72.

[58] Kang H-Y, Park S-J, Kim Y-S. Moisture sorption and ultrasonic velocity of artificially weathered spruce. Mokchae Konghak. 2002;30:18-24.

[59] Åkerholm M, Hinterstoisser B, Salmén L. Characterization of the crystalline structure of cellulose using static and dynamic FT-IR spectroscopy. Carbohydrate Research. 2004;339:569-78.

[60] Tolvaj L, Faix O. Artificial ageing of wood monitored by DRIFT spectroscopy and CIE L*a*b* color measurements. Holzforschung. 1995;49:397-404.

[61] Hon DNS. ESCA STUDY OF OXIDIZED WOOD SURFACES. Journal of Applied Polymer Science. 1984;29:2777-84.

[62] Sernek M, Kamke FA, Glasser WG. Comparative analysis of inactivated wood surface. Holzforschung. 2004;58:22-31.

[63] Kamdem DP, Riedl B, Adnot A, Kaliaguine S. ESCA spectroscopy of poly (methyl methacrylate) grafted onto wood fibers. Journal of Applied Polymer Science. 1991;43:1901-12. 
[64] GeÌrardin P, PetricìtE M, Petrissans M, Lambert J, Ehrhrardt JJ. Evolution of wood surface free energy after heat treatment. Polymer Degradation and Stability. 2007;92:653-7.

[65] Shen Q, Mikkola P, Rosenholm JB. Quantitative characterization of the subsurface acid-base properties of wood by XPS and Fowkes theory. Colloids and Surfaces A: Physicochemical and Engineering Aspects. $1998 ; 145: 235-41$

[66] Koubaa A, Riedl B, Koran Z. Surface analysis of press dried-CTMP paper samples by electron spectroscopy for chemical analysis. Journal of Applied Polymer Science. 1996;61:545-52.

[67] Sinn G, Reiterer A, Stanzl-Tschegg SE. Surface analysis of different wood species using X-ray photoelectron spectroscopy (XPS). Journal of Materials Science. 2001;36:4673-80.

[68] Hua X, Kaliaguine S, Kokta BV, Adnot A. Surface analysis of explosion pulps by ESCA Part 1. Carbon (1s) spectra and oxygen-to-carbon ratios. Wood Science and Technology. 1993;27:449-59.

[69] Fengel D, Wegener G. Lignin - Polysaccharide complexes. Wood: Chemistry, Ultrastructure, Reactions. 2003:167-74.

[70] Kocaefe D, Poncsak S, Boluk Y. Effect of thermal treatment on the chemical composition and mechanical properties of birch and aspen. BioResources. 2008;3:517-37.

[71] Temiz A, Terziev N, Eikenes M, Hafren J. Effect of accelerated weathering on surface chemistry of modified wood. Applied Surface Science. 2007;253:5355-62.

[72] Kotilainen RA, Toivanen TJ, Alén RJ. FTIR monitoring of chemical changes in softwood during heating. Journal of Wood Chemistry and Technology. 2000;20:307-20. 
Table 1 Classification of carbon and oxygen peak components for wood materials

\begin{tabular}{|c|c|c|c|}
\hline \multirow{2}{*}{$\begin{array}{l}\text { Group } \\
\text { Carbon }\end{array}$} & \multirow{2}{*}{$\begin{array}{l}\text { Chemical shifts / peak } \\
\text { position (ev) }\end{array}$} & \multicolumn{2}{|c|}{ Carbon or oxygen bond to } \\
\hline & & & \\
\hline $\mathrm{C}_{1}$ & 284.6 & $\mathrm{C}-\mathrm{C}, \mathrm{C}-\mathrm{H}$ & $\begin{array}{l}\text { Carbon atoms bonded only with carbon or } \\
\text { hydrogen atoms }\end{array}$ \\
\hline $\mathrm{C}_{2}$ & $284.6+1.5 \pm 0.2$ & $\mathrm{C}-\mathrm{O}$ & Carbon atoms bonded with one oxygen atom \\
\hline $\mathrm{C}_{3}$ & $284.6+2.8 \pm 0.2$ & $\mathrm{C}=\mathrm{O}, \mathrm{O}-\mathrm{C}-\mathrm{O}$ & $\begin{array}{l}\text { Carbon atoms bonded to a carbonyl or two } \\
\text { non-carbonyl oxygen atoms }\end{array}$ \\
\hline $\mathrm{C}_{4}$ & $284.6+3.75 \pm 0.2$ & $\mathrm{O}-\mathrm{C}=\mathrm{O}$ & $\begin{array}{l}\text { Carbon atoms bonded to one carbonyl and } \\
\text { one non-carbonyl oxygen atoms }\end{array}$ \\
\hline \multicolumn{4}{|r|}{ 急 } \\
\hline $\mathrm{O}_{1}$ & 531.4-532.3 & $\mathrm{O}-\mathrm{C}=\underline{\mathrm{O}}$ & \\
\hline $\mathrm{O}_{2}$ & $533.0-534.0$ & C-O- & \\
\hline
\end{tabular}


Table 2 Characteristic bands of IR absorption spectra in wood

\begin{tabular}{|c|c|c|}
\hline $\begin{array}{l}\text { Wavenumber } \\
\left(\mathrm{cm}^{-1}\right)\end{array}$ & $\begin{array}{l}\text { Functional } \\
\text { Group }\end{array}$ & Assignment \\
\hline $3500-3420$ & $-\mathrm{OH}$ & Present in water and three wood polymer components $[45,60,70]$ \\
\hline 2900 & $\mathrm{C}-\mathrm{H},-\mathrm{CH}_{2}-$ & Stretching in methyl and methylene group, Hydrocarbon chains $[45,60]$ \\
\hline $1740-1730$ & $-\mathrm{COOH}(\mathrm{C}=\mathrm{O})$ & $\begin{array}{l}\text { free carbonyl groups[55], Stretching of acetyl or carboxylic acid } \\
\text { (hemicelluloses), [53, 60] }\end{array}$ \\
\hline $1640-1660$ & $\mathrm{C}=\mathrm{O}$ & quinines and quinine methides[71], adsorbed water[72] \\
\hline 1600 & $\mathrm{C}=\mathrm{C}$ & Aromatic ring (lignin) [71] \\
\hline 1510 & $\mathrm{C}=\mathrm{C}$ & $\begin{array}{l}\text { Aromatic ring (lignin), stronger } \\
\text { guaiacyl element than syringyl[53, 71] }\end{array}$ \\
\hline 1465 & $\mathrm{C}-\mathrm{H}$ & Asymmetric bending in $\mathrm{CH}_{3}$ (lignin) [53] \\
\hline 1426 & $\mathrm{CH}_{2}$ & $\begin{array}{l}\text { Aromatic skeletal vibrations (lignin) and C-H deformation in } \\
\text { plane (cellulose) [72] }\end{array}$ \\
\hline 1373 & $\mathrm{C}-\mathrm{H}$ & $\begin{array}{l}\mathrm{C}-\mathrm{H} \text { bending. - } \mathrm{CH},-\mathrm{CH} \text {, (carbohydrates. LCC(lignin } \\
\text { carbohydrate complexes) bonds [72] }\end{array}$ \\
\hline $1335-1330$ & $\mathrm{O}-\mathrm{H}$ & phenol group (cellulose) [72] \\
\hline 1316 & $\mathrm{CH}_{2}$ & High crystalline cellulose I (cellulose) [53] \\
\hline $1267-1270$ & $\mathrm{CO}$ & $\begin{array}{l}\text { Guaiacyl ring breathing with CO-stretching (lignin and hemicelluloses) } \\
\text { [71], esters[72] }\end{array}$ \\
\hline 1230 & & Syringyl nuclei [53] \\
\hline 1158 & $\mathrm{C}-\mathrm{O}-\mathrm{C}$ & Carbohydrate[56, 72], \\
\hline 1103 & $\mathrm{C}-\mathrm{H}$ & Guaiacyl and syringyl (lignin) [54] \\
\hline $1030-1050$ & $\mathrm{C}-\mathrm{O}, \mathrm{C}-\mathrm{H}$ & Primary alcohol, guaiacyl(lignin)[54, 72] \\
\hline 896 & & $\mathrm{C}_{1}$-carbon in pyranoid ring (in cellulose and hemicelluloses)[72] \\
\hline 813-806 & $\mathrm{C}-\mathrm{H}$ & $\begin{array}{l}\text { Mainly vibration of mannan and C-H out of plane bending vibration in } \\
\text { lignin (lignin) [1] }\end{array}$ \\
\hline
\end{tabular}



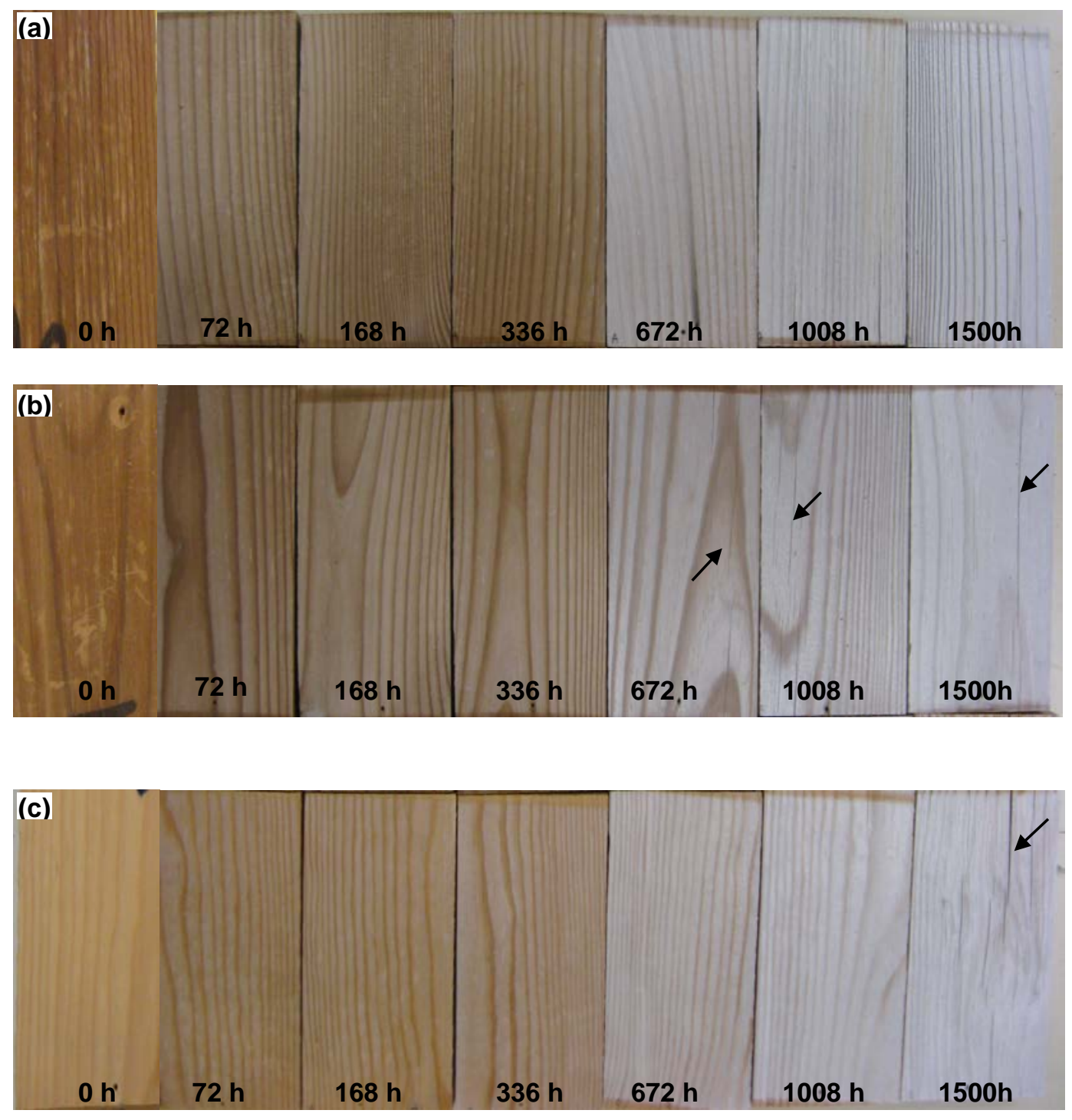

Fig. 1 Jack pine surfaces during artificial sunlight irradiation: (a) radial surface of heat-treated wood, (b) tangential surface of heat-treated wood, (c) tangential surface of untreated wood 

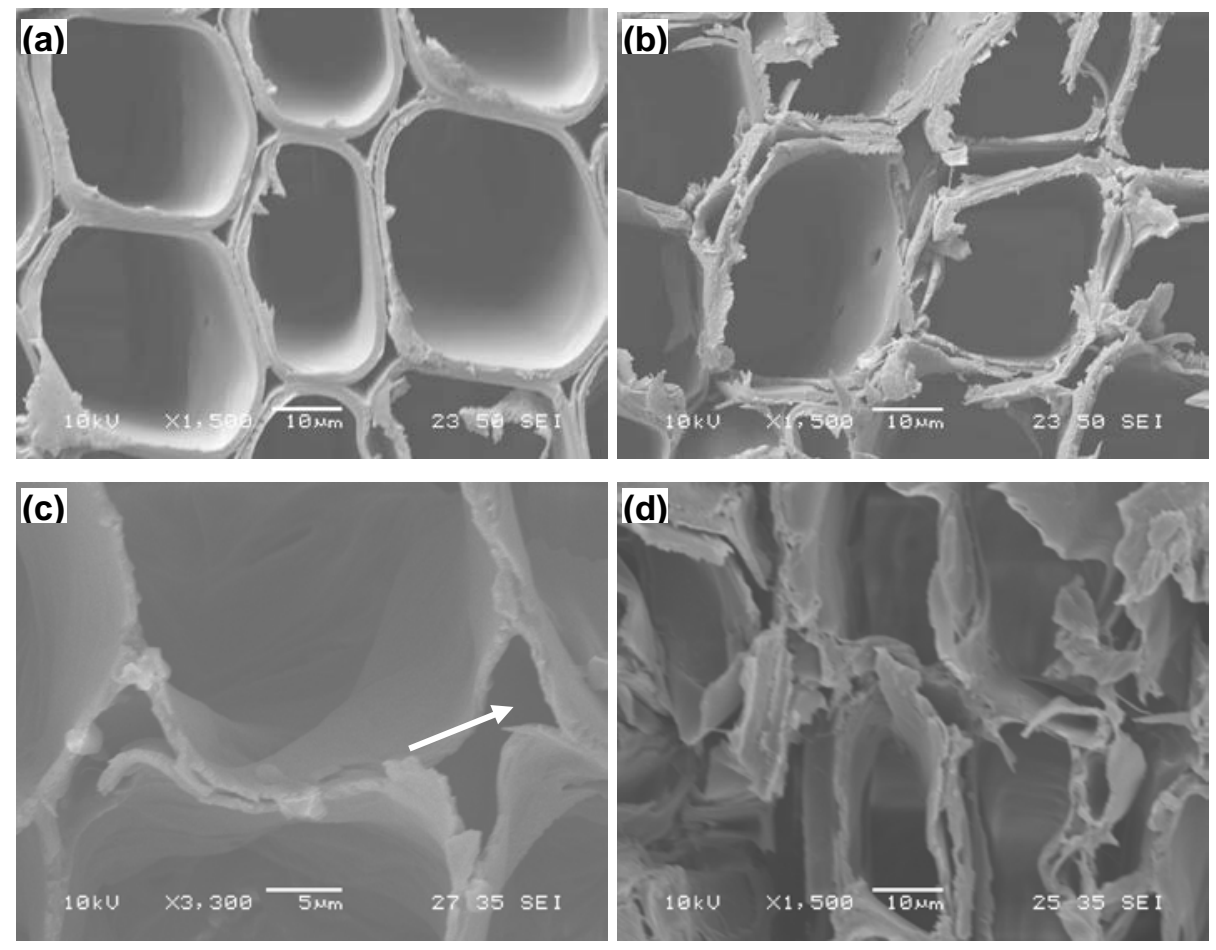

Fig. 2 SEM images comparing the structural changes of earlywood tracheids on transverse surface due to heat treatment and exposure to artificial sunlight irradiation for $1500 \mathrm{~h}$ : (a) untreated before exposure; (b) heat-treated before exposure; (c) untreated after exposure; (d) heat-treated after exposure; 

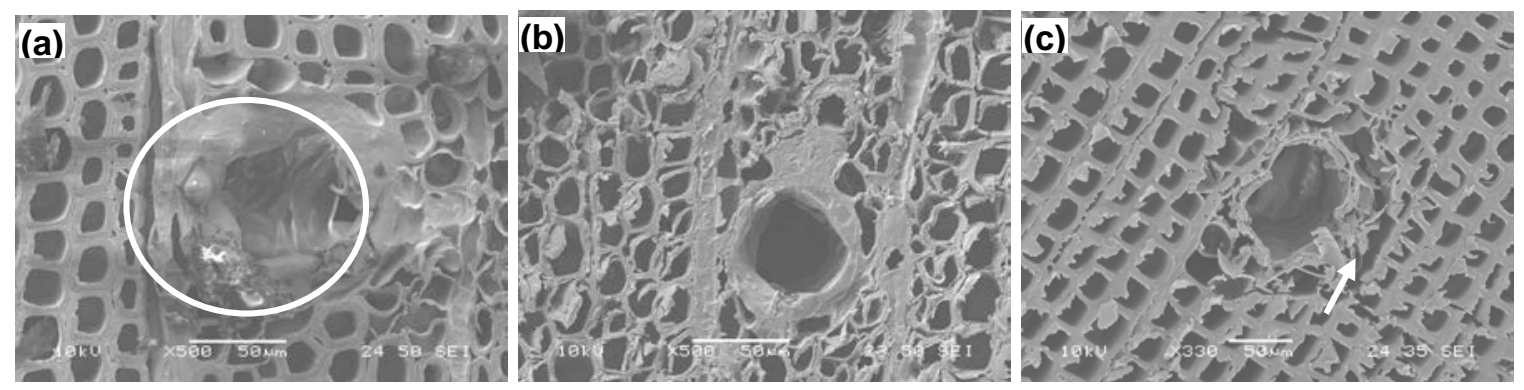

Fig. 3 SEM images of resin channels on heat-treated jack pine transverse surfaces before and after artificial sunlight irradiation: (a) untreated before exposure; (b) heat-treated before exposure; (c) heat-treated after exposure of $336 \mathrm{~h}$ 

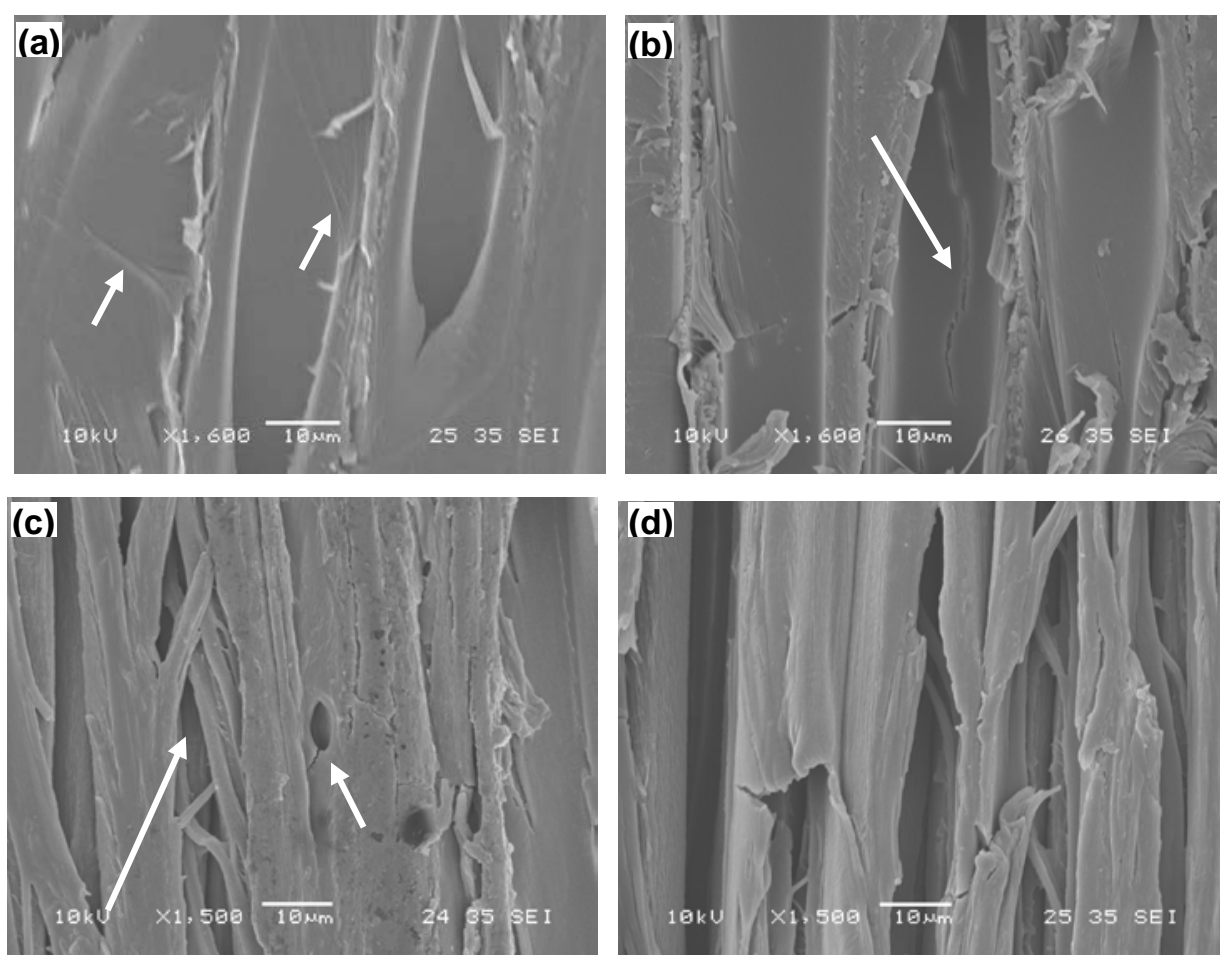

Fig. 4 SEM image showing micro-cracks on tracheid cell wall of tangential surface of jack pine latewood due to heat treatment and artificial sunlight irradiation: (a) untreated before irradiation; (b) heat-treated before irradiation; (c) heat-treated after irradiation for $672 \mathrm{~h}$; (d) heat-treated after irradiation for $1500 \mathrm{~h}$ 

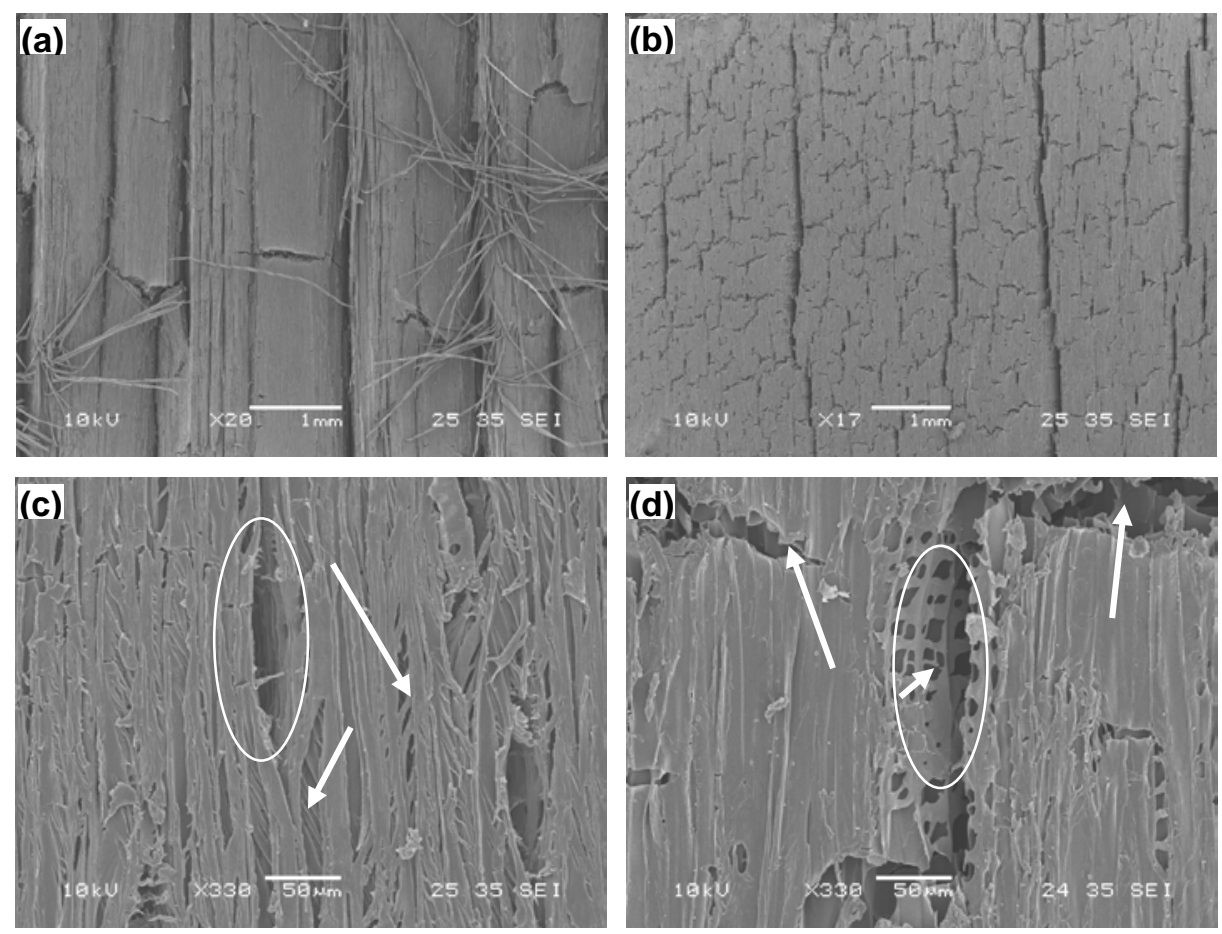

Fig. 5 SEM images comparing cracks on heat-treated jack pine due to artificial sunlight irradiation: (a) radial surface irradiated for 1500 h, (b) tangential surface irradiated for 1500 h; (c) earlywood irradiated for 336 h; (d) latewood irradiated for $336 \mathrm{~h}$ 

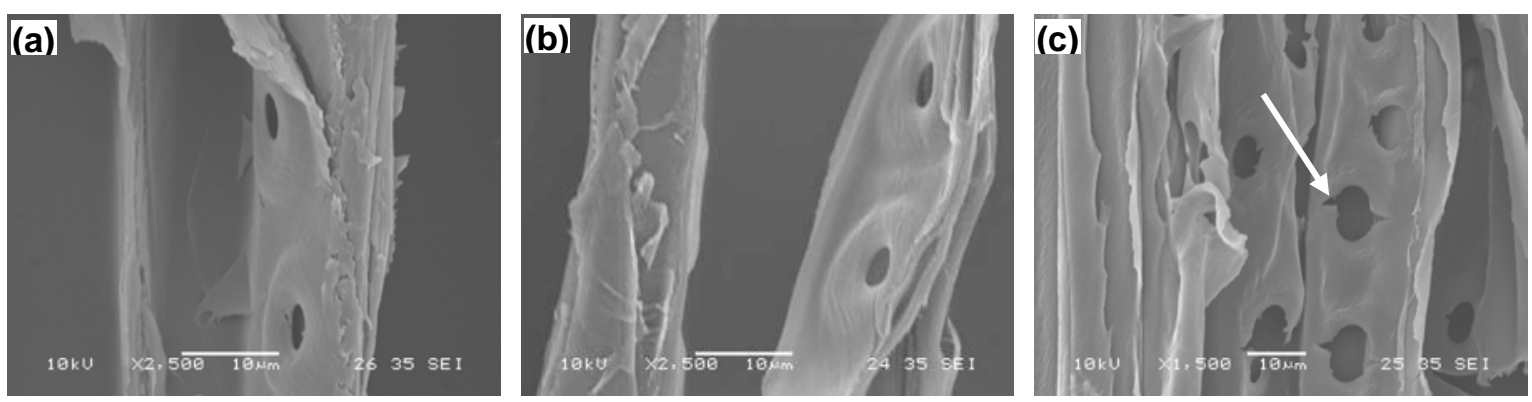

Fig. 6 Cross sections of bordered pits between longitudinal tracheids on radial surfaces of jack pine: (a) untreated before irradiation; (b) heat-treated before irradiation; (c) heat-treated after irradiation for $1500 \mathrm{~h}$ 

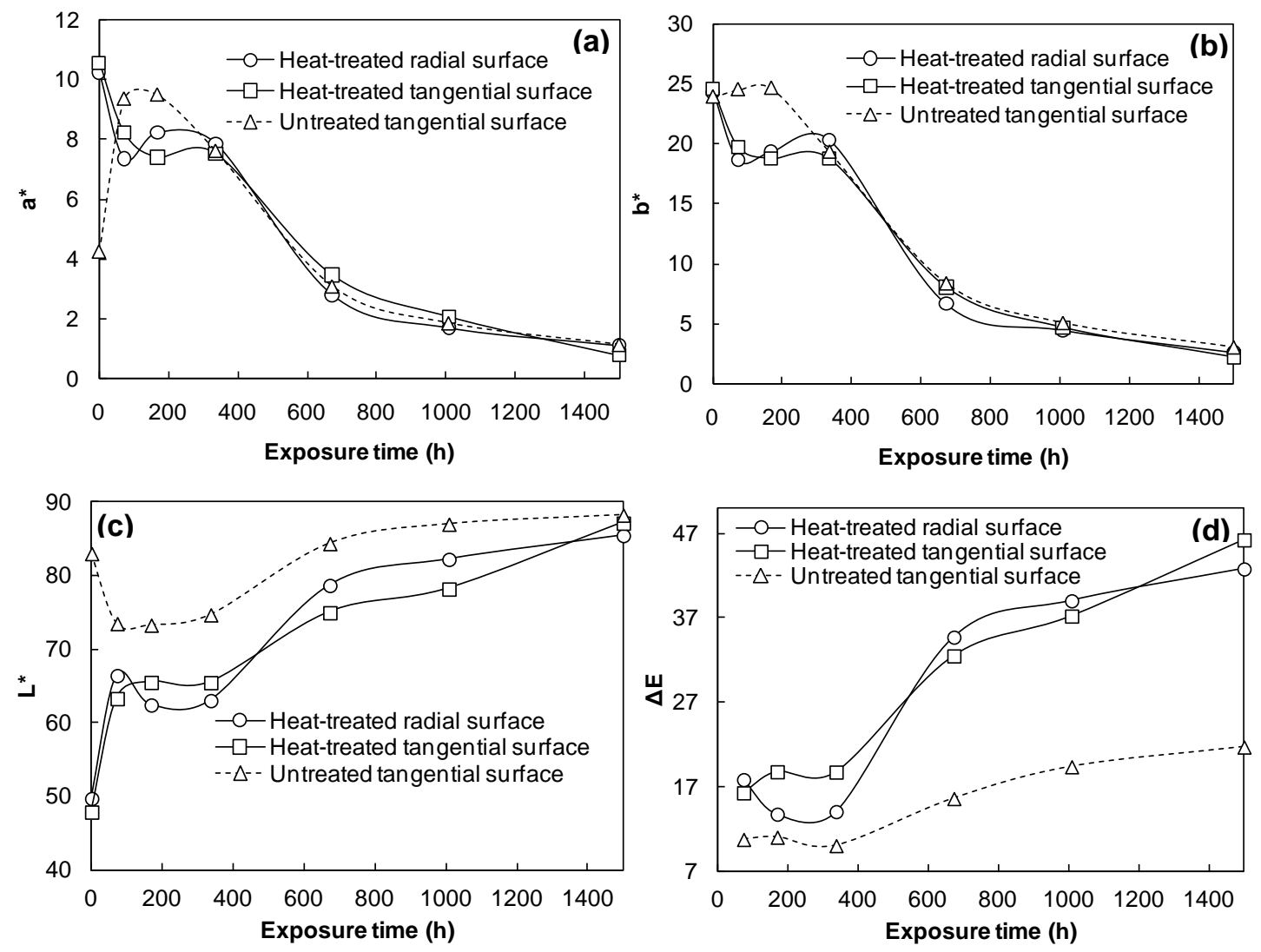

Fig. 7 Color changes of jack pine surface during artificial sunlight irradiation: (a) red/green coordinate (a*), (b) yellow/blue coordinate $\left(b^{*}\right)$, (c) lightness coordinate $\left(\mathrm{L}^{*}\right)$, (d) total color difference $(\Delta \mathrm{E})$ 


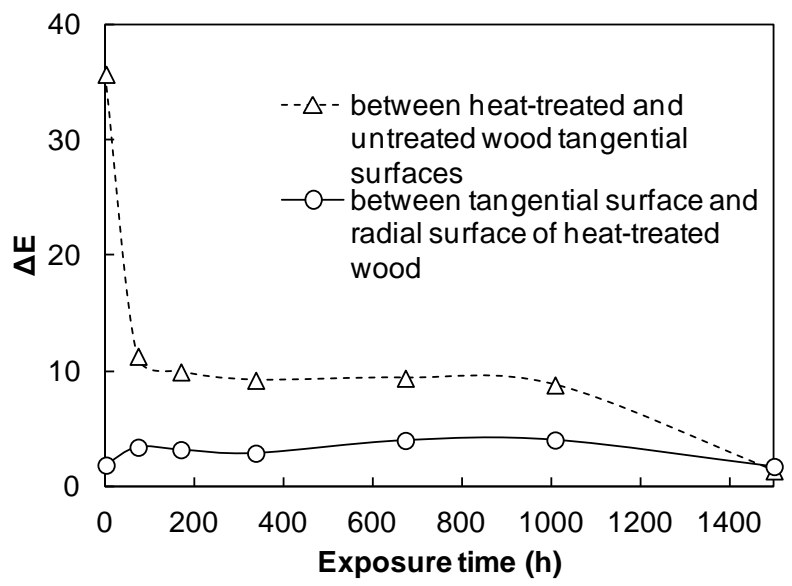

Fig. 8 Total color difference between different specimens at the same artificial sunlight irradiation stage 

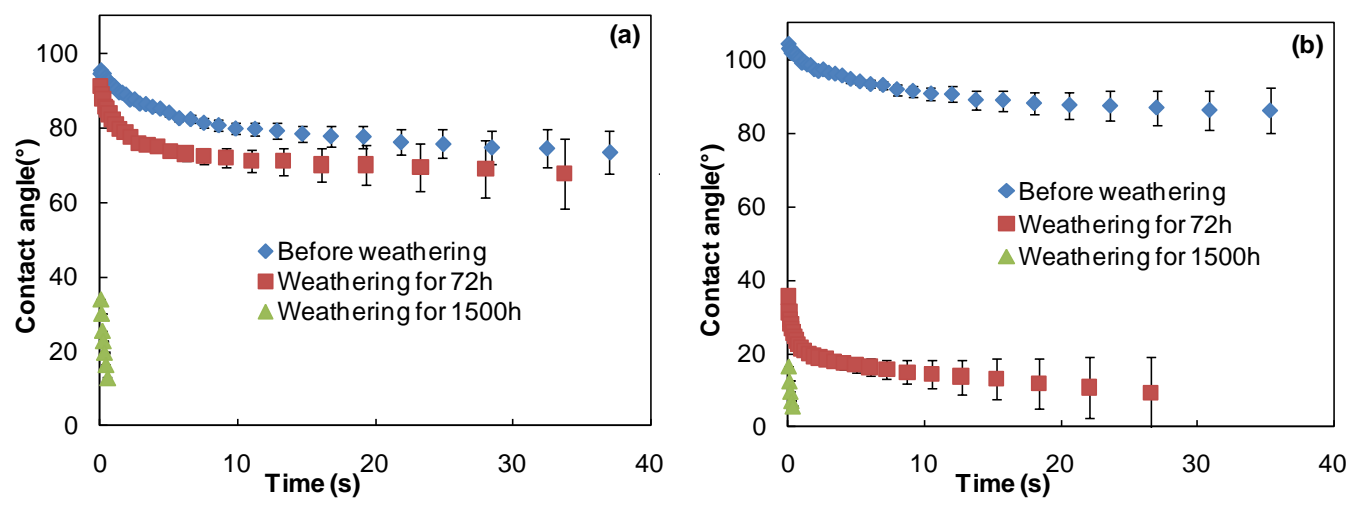

Fig. 9 Wettability on tangential surfaces of jack pine latewood before and after artificial sunlight irradiation for different periods: (a) untreated wood, (b) heat-treated wood 


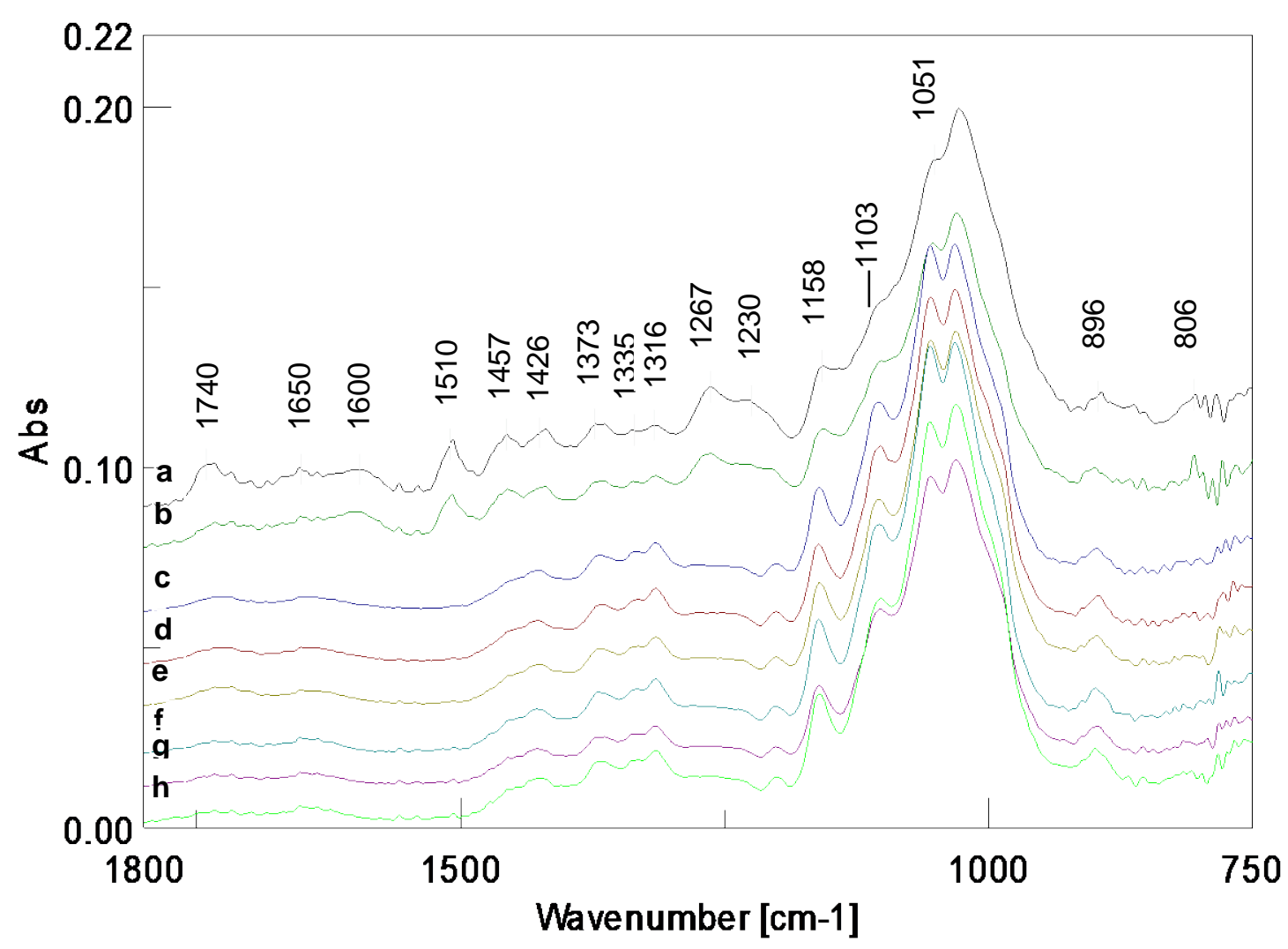

Fig. 10 FTIR spectra of heat-treated jack pine during artificial sunlight irradiation: (a) untreated before irradiation, (b-h) heat-treated samples irradiated for : (b) 0 h, (c) 72 h, (d) 168 h, (e) 336 h, (f) 672 h, (g) 1008 h, (h) 1500 h 

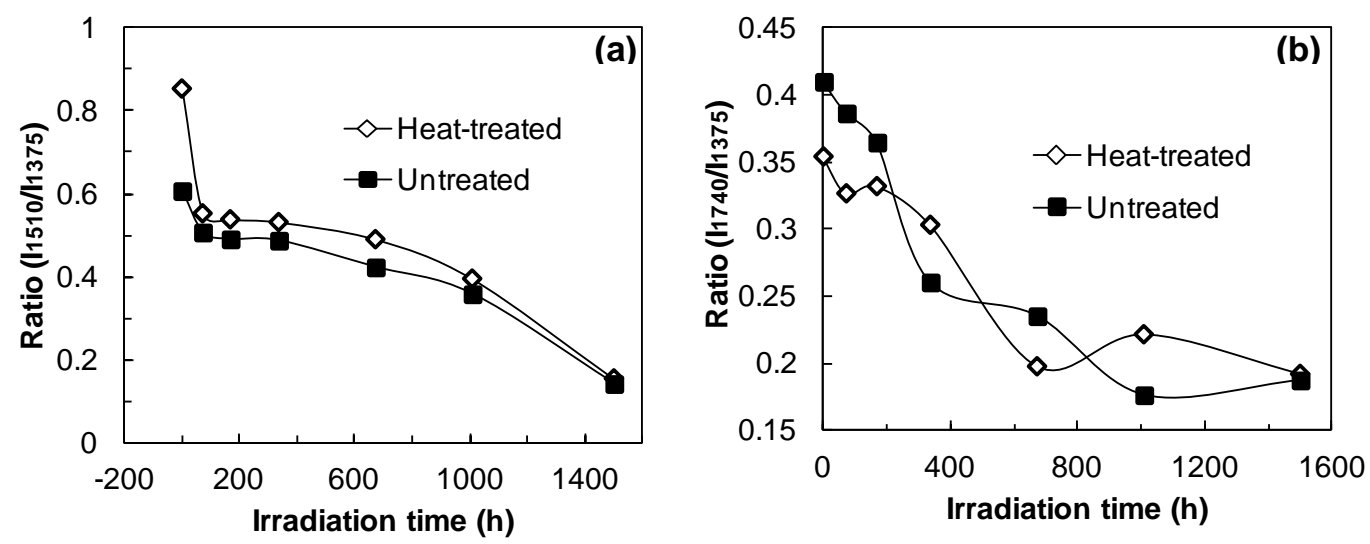

Fig. 11 (a)Variation of ratio of lignin at $1510 \mathrm{~cm}^{-1}$ against carbohydrate at $1375 \mathrm{~cm}^{-1}$ as a function of irradiation time, (b) Behavior of band at $1740 \mathrm{~cm}^{-1}$ against carbohydrate at $1375 \mathrm{~cm}^{-1}$ plotted against irradiation time for heattreated and untreated jack pine 

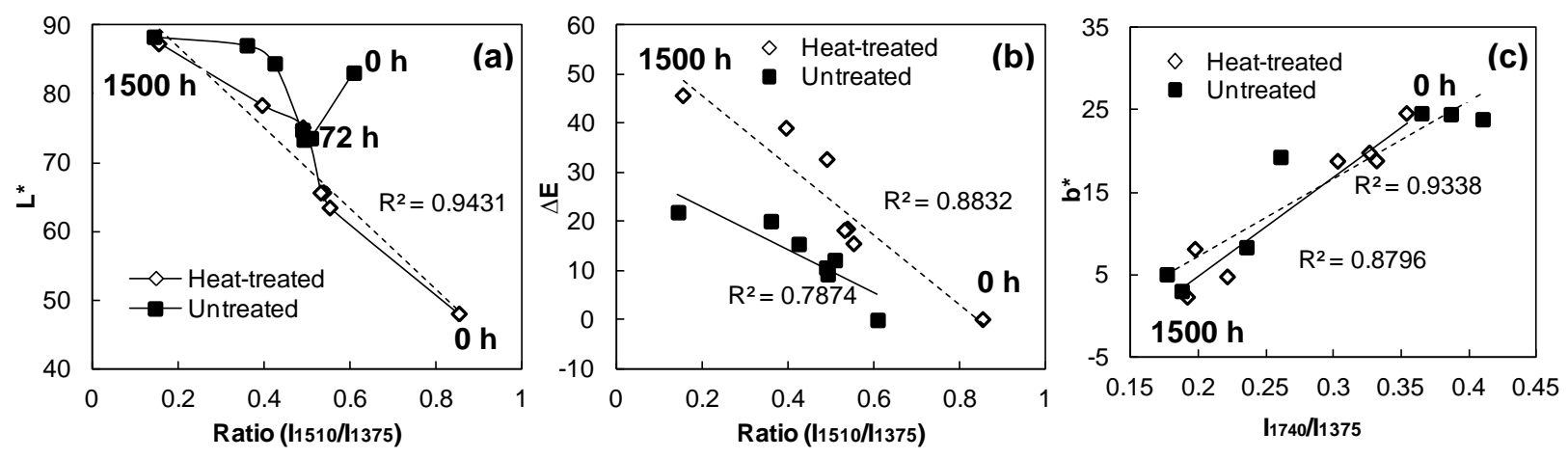

Fig. 12 Relationship of color changes with function groups of heat-treated and untreated jack pine during irradiation: (a) lightness and decay of lignin, (b) total color changes and decay of lignin, (c) b* and carbonyl groups content 

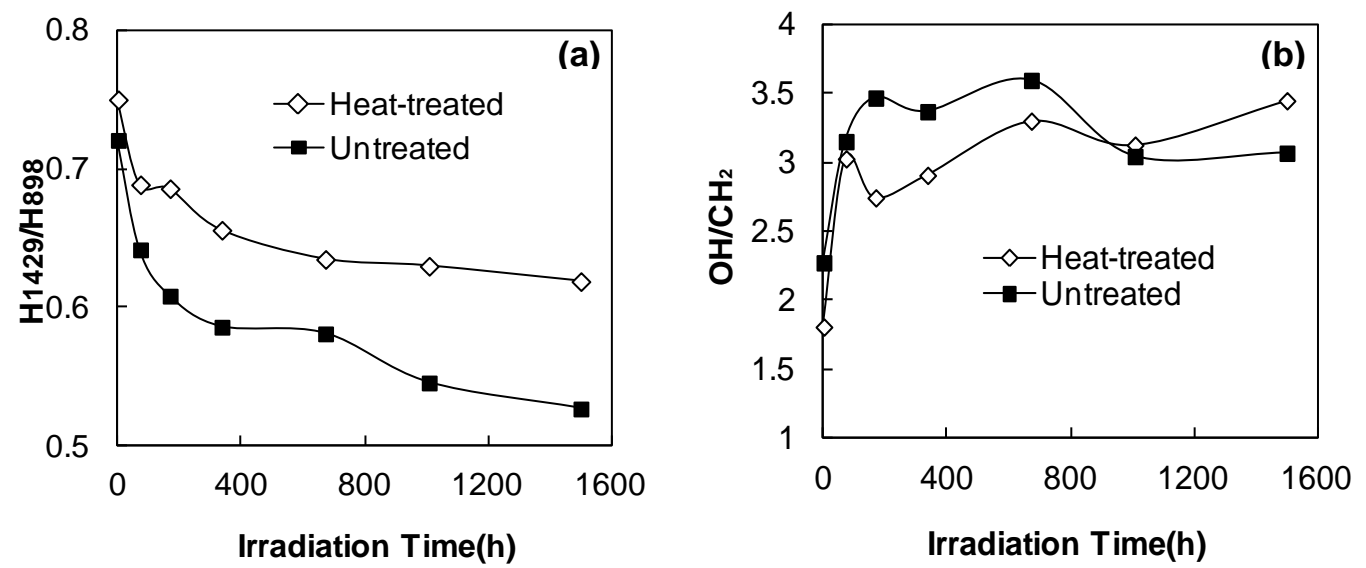

Fig. 13 (a) Crystallinity $\left(\mathrm{H}_{1429} / \mathrm{H}_{898}\right)$ during irradiation, (b) Intensity ratios of bands at $3500 \mathrm{~cm}^{-1}\left(\mathrm{OH} / \mathrm{CH}_{2}\right.$ ratio) to band at $2900 \mathrm{~cm}^{-1}$ in FTIR spectra 

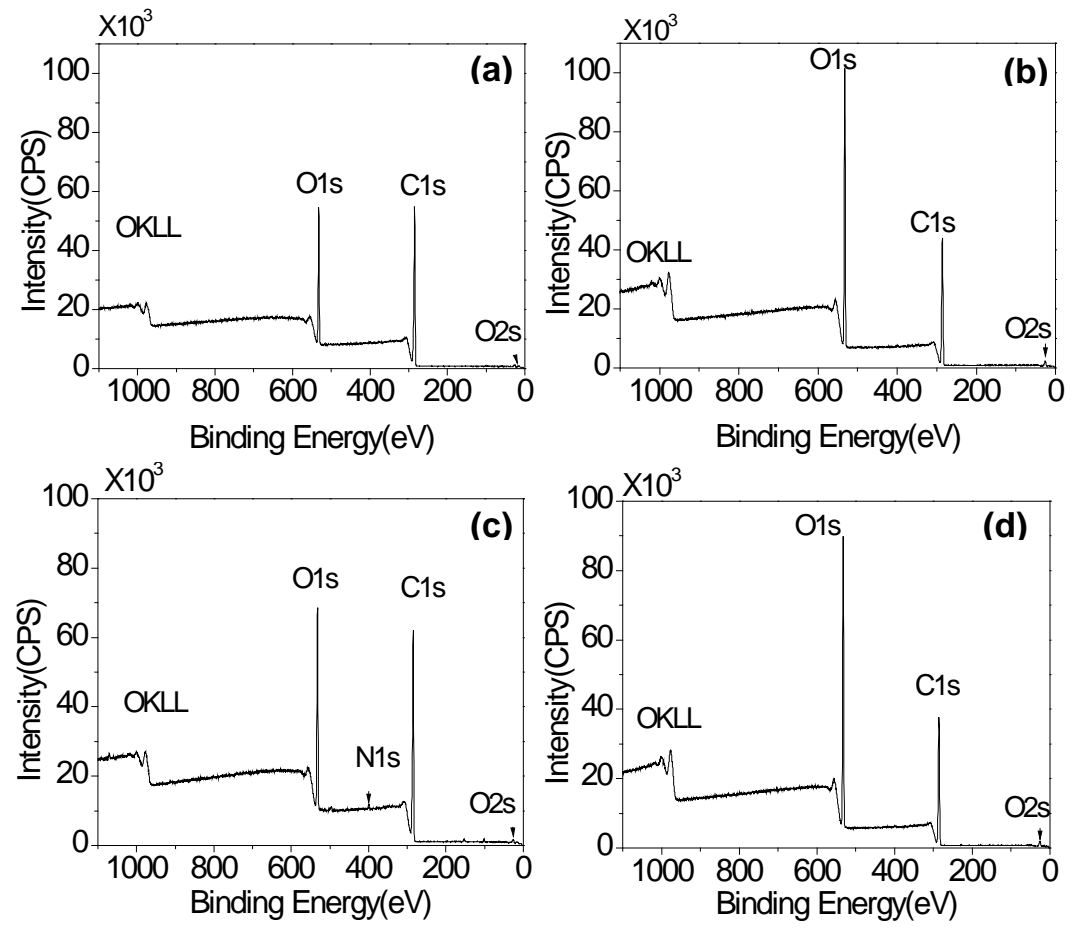

Fig. 14 XPS survey spectra of untreated and heat-treated jack pine wood before and after irradiation for 1500 h: (a) untreated before irradiation, (a) untreated irradiated for $1500 \mathrm{~h}$, (a) heat-treated before irradiation, (a) heat-treated irradiated for $1500 \mathrm{~h}$ 


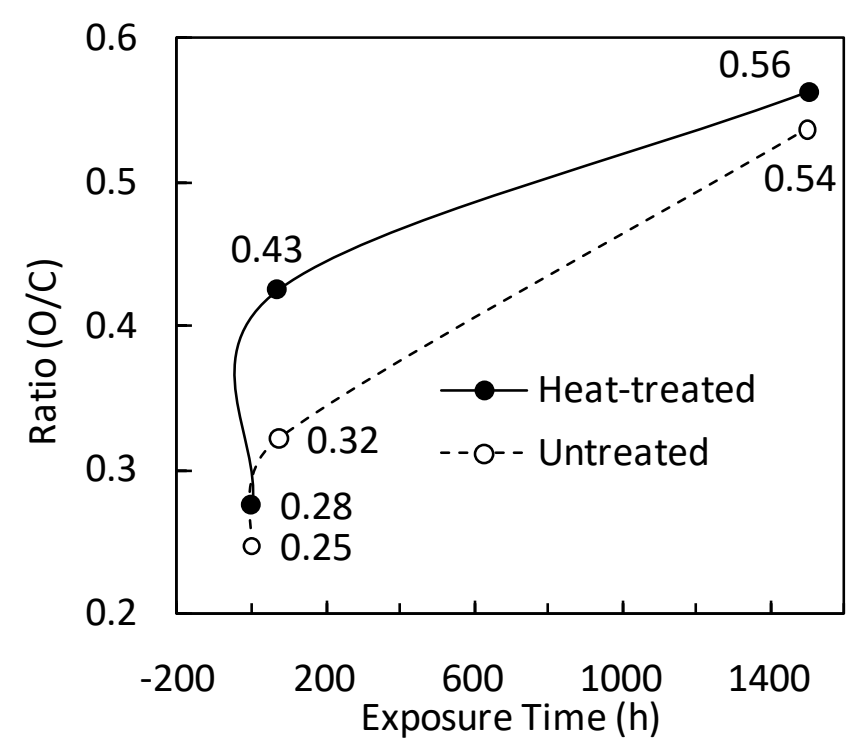

Fig. 15 O/C Ratio of untreated and heat-treated jack pine wood surface during irradiation 

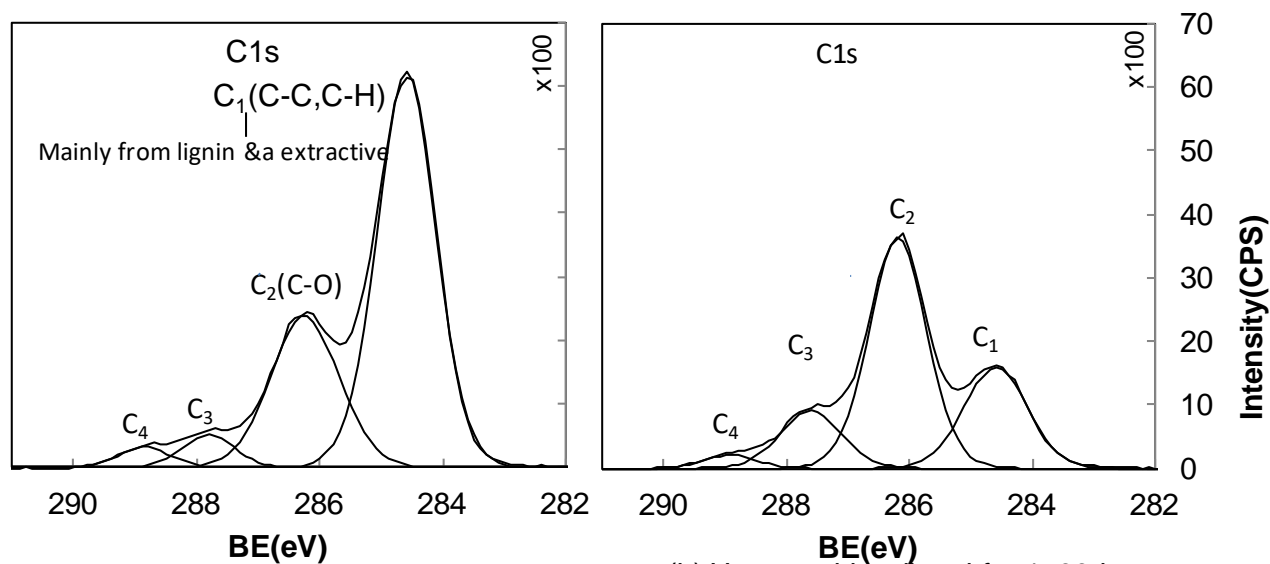

(a) Untreated before irradiation

(b) Untreated irradiated for $1500 \mathrm{~h}$

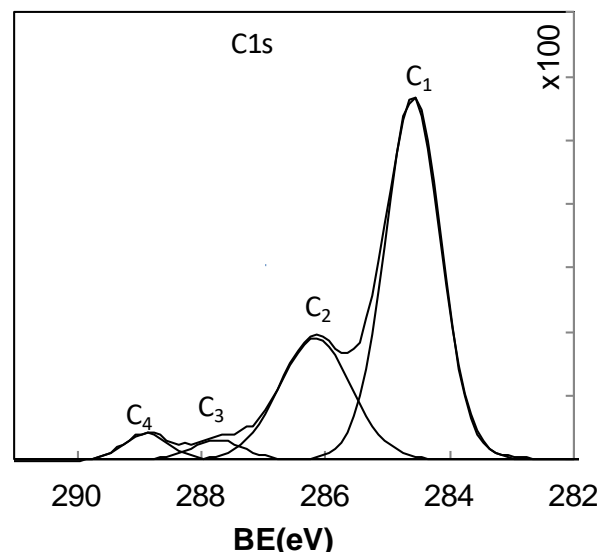

(c) Heat-treated before irradiation

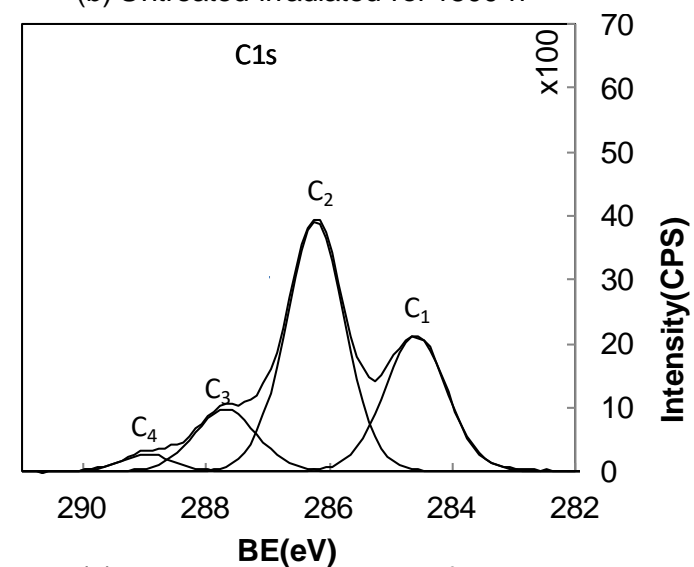

(d) Heat-treated irradiated for $1500 \mathrm{~h}$

Fig. 16 C1s spectra of untreated and heat-treated jack pine wood before and after irradiation for $1500 \mathrm{~h}$ 


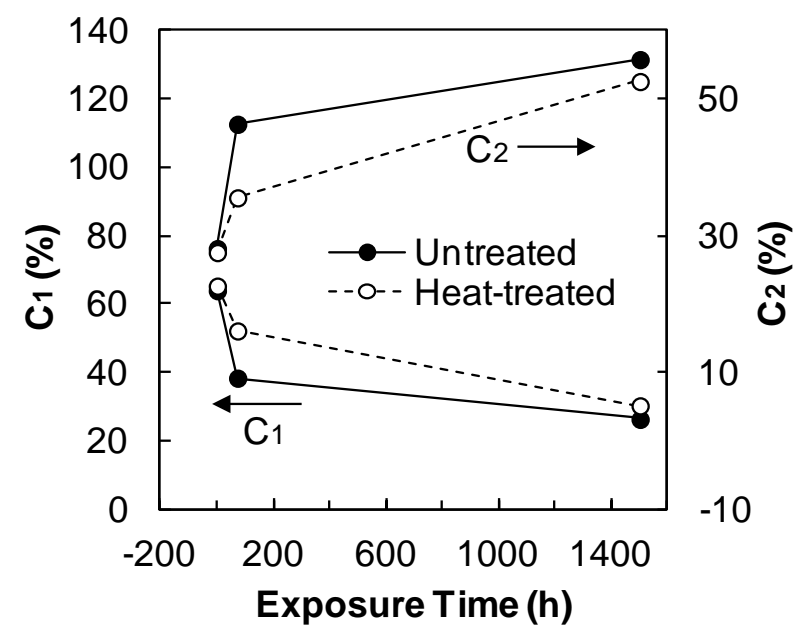

Fig. 17 Effect of irradiation on the $\mathrm{C} 1$ and $\mathrm{C} 2$ component on heat-treated and untreated jack pine surface 


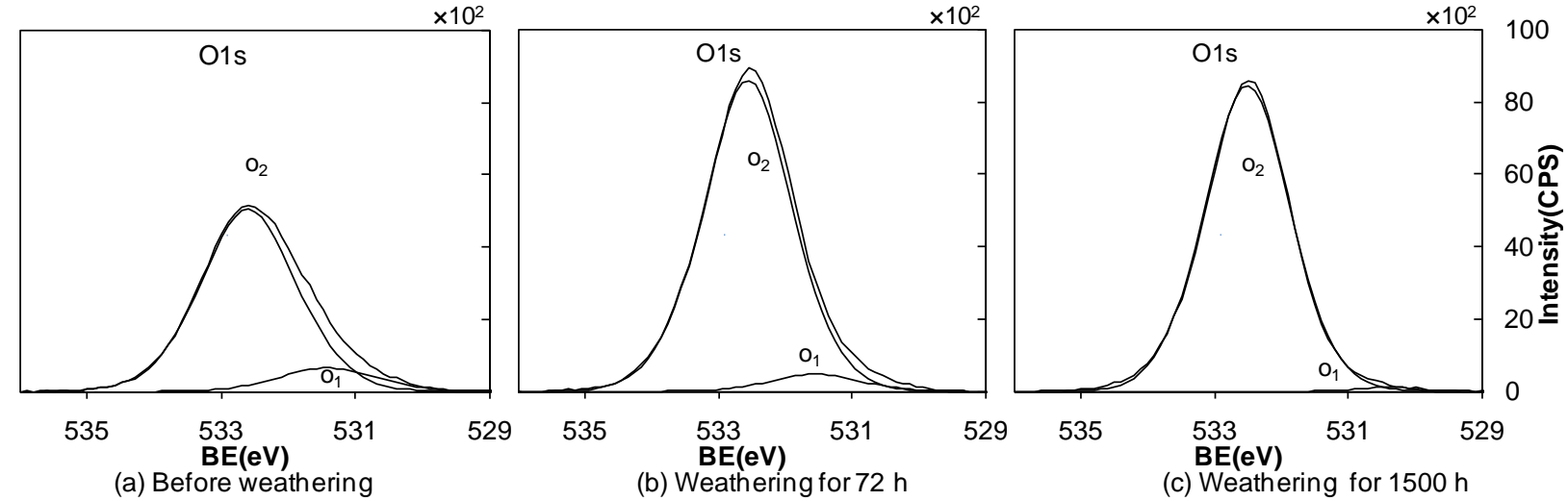

Fig. 18 O1s peaks of heat-treated wood during different irradiation times 


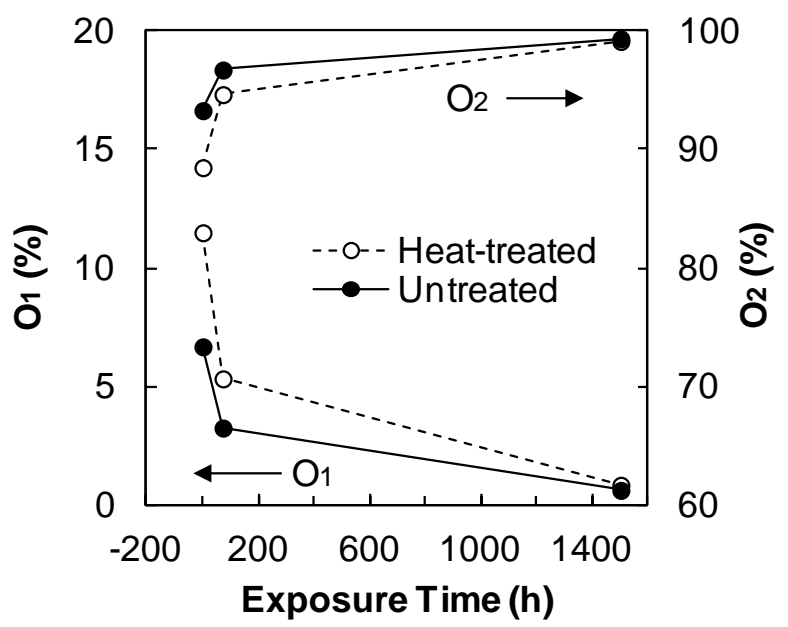

Fig. 19 Effect of irradiation on $\mathrm{O} 1$ and $\mathrm{O} 2$ component of heat-treated and untreated jack pine surface 